\title{
PUBLIC PERCEPTION OF COASTAL ZONE ENVIRONMENTAL PROBLEMS IN THE SAMSUN PROVINCE, TURKEY
}

\section{ZAZNAVANJE OKOLJSKIH PROBLEMOV V JAVNOSTI V OBALNEM OBMOCJU OKROZJJA SAMSUN V TURCIJI}

Kemalettin Şahin

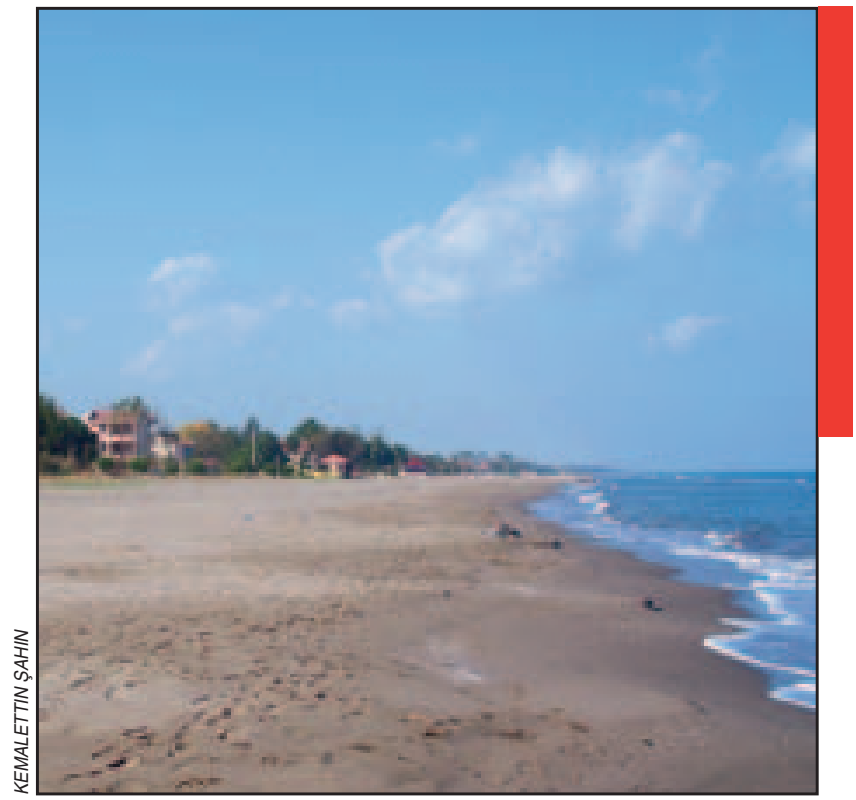

Samsun province has broad and extensive beaches:

Samsun beach panorama at Incesu.

V pokrajini Samsun so obsežne plaže: plaža pri mestu Incesu. 


\title{
Public perception of coastal zone environmental problems in the Samsun province, Turkey
}

DOI: $10.3986 / A G S 49207$

UDC: 91:504.5(560.624)

COBISS: 1.01

\begin{abstract}
During the past few decades, the Samsun coast has been subjected to various human impacts that have led to changes in the coastal zone of this the area. This paper is an attempt to understand and define how residents and beach users perceive coastal zone problems in Samsun province based on their perceptions. For this purpose, a questionnaire survey was conducted during the months of June and July in 2005 and 2006 on 500 residents and beach users at eight beaches along the 121-kilometer Samsun shoreline on the north side of Turkey. The questionnaire data was collected through a direct interview. Analysis of interview data reveals that the respondents perceive coastal seawater pollution (89\%), beach pollution, the loss of beach plain (67\%), and changes in land use (91\%) as the main problems of the coastal zone. The main factors blamed for coastal seawater pollution are sewage (98\%), industrial waste (74\%), and waste oils discharged by ships (38\%). It is clear from the results of the survey that residents and beach users are not sufficiently aware of the coastal zone problems. The most important recommendation for solving these problems is increasing environmental awareness. To this end, environmental education activities are necessary for the conservation of coastal zone ecosystems.
\end{abstract}

KEY WORDS: geography, coastal pollution, public perception, sewage, Samsun, Turkey

The article was submitted for publication on February 18, 2008.

ADDRESS:

Kemalettin Şahin, Ph. D.

Department of Geography, Faculty of Arts And Science, Ondokuz Mayıs University

55139 Kurupelit, Samsun, Turkey

E-mail:ksahin@omu.edu.tr

\section{Contents}

1 Introduction 431

2 Methodology 431

2.1 Investigation areas 431

2.2 Data and Methods 432

3 Results 434

4 Discussion 439

5 Conclusion 440

6 References 441 


\section{Introduction}

Within the last five to ten years, the coastal sea and coastal zone degradation in the Samsun region have become serious and important issues. Activities such as recreation, coastal development and urbanization, and quarrying for construction sand in some beach areas have been carried out actively in the studied area. The coastal zone has suffered considerably from reclamation and infrastructure factors such as housing, transport, sewerage and water supply lines, land-acquisition procedures, and coastal parks. Garbage including litter and solid waste on Samsun beaches has become a pollution issue. Morgan et al. (2000) also emphasize that the Samsun region is a minor destination for north European coastal tourists and suffers problems of inadequate infrastructure and pollution. Environmental degradation in coastal zones of Turkey is a serious problem (İrtem et al. 2005). Numerous scientific studies have been done on the pollution of beaches and seas due to litter and garbage in various regions of world (Derraik 2002; Williams et al., 2003; Hartwig et al. 2007).

Turkey is surrounded by the Black Sea, the Marmara Sea, the Aegean Sea, and the eastern Mediterranean Sea. The coastal areas of these seas have a considerable variety of natural and cultural values (Yalçıner, Gökdalay 2000). Coastal regions in particular are the site of economic and recreational activities, with the result that they are threatened by misuse, pollution, and unregulated urbanization caused by overpopulation (Mensah 1997; Morgan et al. 2000; Tzatzanis et al. 2003; İrtem et al. 2005). The necessity to protect coastal seawater and coasts as sensitive ecosystems is frequently stated (Mensah 1997; İrtem et al. 2005). Beaches are important natural sites where both residents and beach users rest, entertain themselves, and relax (Tzatzanis et al. 2003; Tudor and Williams 2006). Various questionnaire survey studies have been done concerning the opinions and observations of beach users regarding the exploitation and protection of beaches and the public's perception of coastal water pollution (Kocasoy 1989a; Mcbride et al. 1998; Baysan 2001; Nordstrom, Mitteager 2001; Pendleton et al. 2001; Nelson, Botterill 2002; Malavasi et al. 2004; Santos et al. 2005; Smrekar 2006; Tudor and Williams 2006).

Samsun Province has broad and extensive beaches, which comprise 213 kilometers of the total coastline. Along with geomorphological factors, a further reason for their existence is the influence of the Kızılırmak River, Turkey's longest river $(1,355 \mathrm{~km})$, the Yeşilırmak River $(519 \mathrm{~km})$, and dozens of small creeks discharging their waters into the Black Sea within the boundaries of the province. Situated between the foothills of Mount Canik and the Black Sea, Samsun beaches are composed of fine sand. The granulation structure of the beach sand in the studied area has small and medium thickness, between $0.0625 \mathrm{~mm}$ and $1 \mathrm{~mm}$ in diameter according to the Wentworth classification (Şahin 2005b). The width of the beaches reaches fifty meters in some places.

The aims of this paper are to:

- investigate the different perceptions and opinions of beach users on aspects related to beach and coastal seawater pollution;

- identify coastal zone environmental problems and their causes in areas occupied by beach users;

- determine the level of public awareness of coastal zone environmental problems; and

- identify individual measures implemented for the protection beaches and coastal seawater from pollution where people view and use the coastline.

The other objective of the survey was to contribute to national and regional coastal zone policy making. Existing public perception studies regarding Samsun beaches are insufficient, and for this reason the methods applied in this study are different from other studies.

\section{Methodology}

\subsection{Investigation area}

The investigation area is roughly located between $41^{\circ} 08^{\prime}-41^{\circ} 44^{\prime}$ northern latitudes and $35^{\circ} 20^{\prime}-37^{\circ} 14^{\prime}$ eastern longitudes and lies east and west of the city of Samsun. The Black Sea coasts in northern Turkey include both steep and low coastlines due to the mountains lying parallel to the shoreline. The Samsun coasts generally consist of low coasts (beaches) since the deltas of Kızılırmak and Yeşilırmak Rivers are in Samsun province (Uzun 2005, 183). The studied area starts from the beach near the town of Çınarlık in 


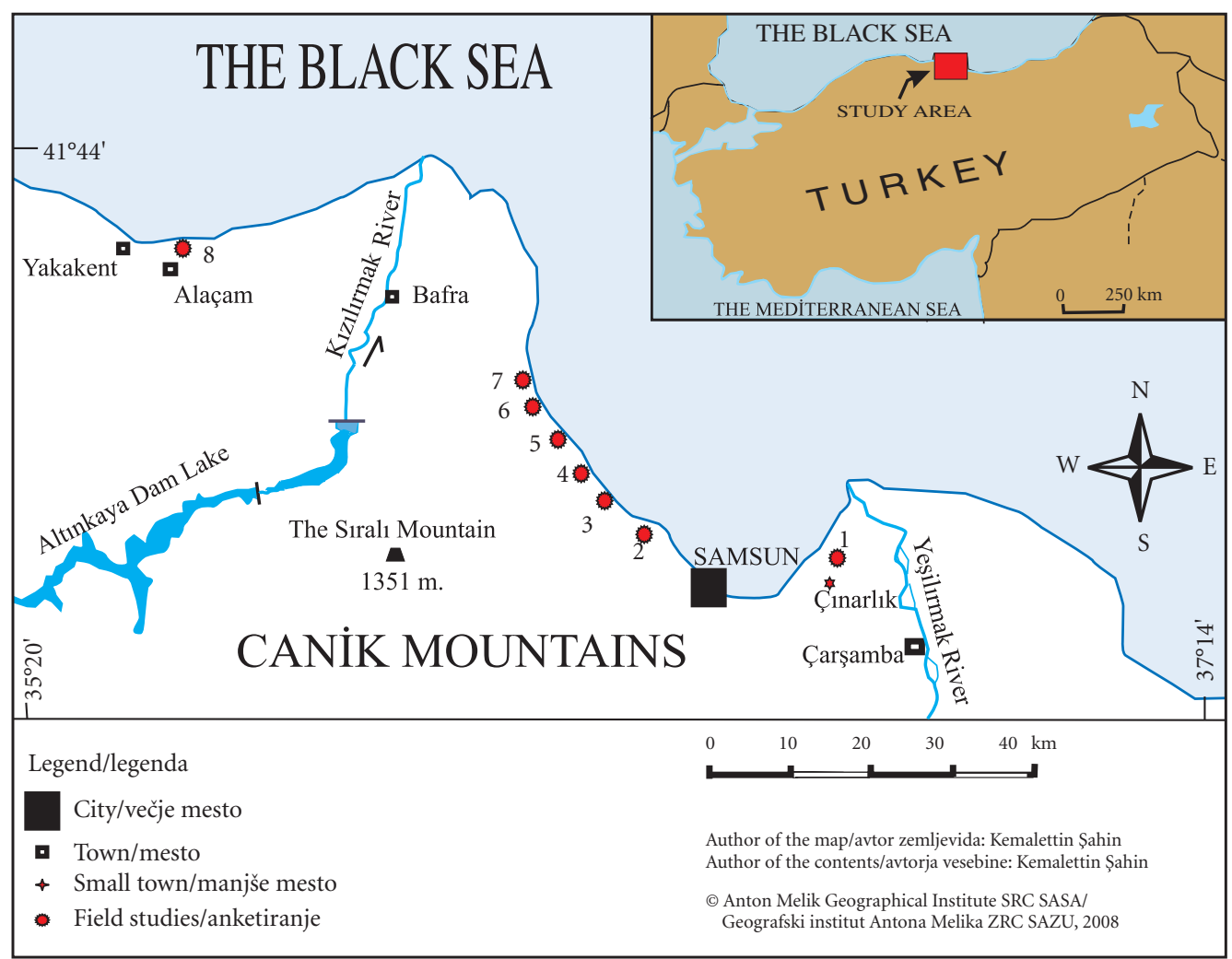

Figure 1: Location of beaches studied. Key: 1 - Costal, 2 - Atakum, 3 - Atakent, 4 - İncesu, 5 - Taflan, 6 - Dereköy, 7 - Ondokuzmayıs, 8 - Geyikkoşan.

the district of Çarşamba City in the east and continues along the 121-kilometer shoreline with interruptions to the beaches of Yakakent in the west (Figure 1).

The topography of the coastline is characterized by beaches, coastal plains, slopes, and mountains. The majority of the settlements and much of the population are situated along the coast below the 100-meter contour line. The Samsun region has a "humid-temperate " climate where the Black Sea climate dominates the coastal belt, has an annual average temperature of $14.3^{\circ} \mathrm{C}$, and does not have great temperature changes during the year due to its small temperature amplitude (Nişanci 1989). According to Morgan et al. (2000, 48), "The Black Sea coastal climate is characterized by a 'cold' thermal sensation early in the season. Samsun offers an excellent climate for beach tourism in what is considered the peak season (July-September) for north European tourists, with near ideal bathing water temperature and pleasant thermal sensation ...".

In the tourist season (from mid June to the end of August), the studied areas are under intensive pressure not only from local residents but also from people coming from nearby districts and provinces. The permanent population of the beach areas is approximately 90,000 , but in the summer months it increases up to five times due to beach users. The Samsun city center has a population of 363,180 (2000 census data).

\subsection{Data and Methods}

The questionnaire survey of residents and beach users was conducted in towns and beaches along the coast during the summers of 2005 and 2006 (Figure 1). Beach users were composed mainly of locals or day-trippers. The survey was conducted over a two-year period at eight beaches; Costal, Atakum, Atakent, İncesu (Altınkum), Taflan, Dereköy, Ondokuz Mayıs, and Geyikkoşan (Alaçam). In total, 271 residential house- 
holders and 229 beach users were interviewed. Interviewing took place from nine in the morning to six in the afternoon on Saturday and Sunday when the beaches were crowded due to the weekend break.

The questions prepared for the questionnaire consisted of investigative and observational items. Questions from Buttimore's survey (2004) were also used. The Statistical Department of the University of Ondokuz Mayis provided useful input in developing the survey methods and the format and content of the questions.

Twelve multiple-choice questions (MCQ) were asked with respondents selecting one choice from a given list of alternatives. Three questions were social sub-group questions identifying sex, age, education, and professions. Seven questions were judgmental multiple-choice questions that exposed the awareness, ideas, beliefs, and perceptions of respondents regarding coastal zone problems (especially beach and coastal seawater pollution). Two questions were multiple-choice questions about the respondents' actual experiences and behaviour. Close-ended question structures were preferred for obtaining answers on the questionnaires.

A recent Turkish census was used to determine the target mass. Demographic population data was provided by the Turkish Statistical Institute (Internet 1). The sample size was suitably formatted_since information obtained from the local community dominates while the number of visitors coming to the beach can not be known precisely. A stratified sample of the beach-using population (local residents and visitors) was obtained using 2000 census data. Before our interviews, a preliminary survey of one hundred of the permanent residents $(84,052)$ of the target group to be studied was done to identify coastal problems affecting residents and beach users in the area between Costal and Yakakent and to help determine the appropriate sample size. Some $80 \%$ of the respondents (P) identified coastal zone problems (coastal seawater and beach pollution, urbanization ...) while $20 \%$ of the respondents did not. As a result, a $95 \%$ confidence interval $(\alpha=0.05)$ was obtained with an index of 1.96 for a $95 \%$ confidence level with a $5 \%$ margin of error. The formulas used to determine an appropriate sample size are shown below:

$\mathrm{N}=\mathrm{Z}^{2} \cdot(\mathrm{P}) \cdot(1-\mathrm{P}) / \mathrm{C}^{2}$ where

$\mathrm{N}=$ sample size (minimum number of respondents required),

$\mathrm{Z}=$ value (1.96 for $95 \%$ confidence level),

$\mathrm{P}=$ percentage identifying coastal problems in Samsun Province,

expressed as decimal ( 0.80 used for sample size needed),

$\mathrm{C}=$ confidence interval, expressed as decimal (0.05).

In our case $\mathrm{N}$ was calculated as follows:

$\mathrm{N}=(1.96)^{2} \cdot[(0.80) \cdot(1-0.80)] /(0.05)^{2}=3.8416 \cdot 0.16 / 0.0025=0.614656 / 0.0025=245$.

For the purposes of our survey, from $\mathrm{T}_{\mathrm{m}}=84,052$, it was necessary to get a suitable sample size $(\mathrm{Ss}=500)$. This figure was proportionally distributed among the areas where the survey was to be carried out according to stratified sampling $\left(\mathrm{S}_{\mathrm{t}}\right)$ using the formula:

$\mathrm{S}=\left(\mathrm{Ss} \cdot \mathrm{S}_{\mathrm{t}}\right) / \mathrm{T}_{\mathrm{m}}$ where

$\mathrm{S}=$ sample size for area,

Ss $=$ total sample size (raised from minimum 245 to 500 total),

$\mathrm{S}_{\mathrm{t}}=$ population of individual area,

$\mathrm{T}_{\mathrm{m}}=$ target mass.

Table 1: Information for each stratum.

\begin{tabular}{llcr}
\hline Stratum & Beaches - areas & Population (2000 census data) & Sample (S) \\
\hline 1 & Cinarlık & $\mathrm{S}_{\mathrm{t}}=2,655$ & 16 \\
2 & Atakum & $\mathrm{S}_{\mathrm{t}}=43,905$ & 260 \\
3 & Atakent & $\mathrm{S}_{\mathrm{t}}=5,064$ & 30 \\
4 & Incesu (Altınkum) & $\mathrm{S}_{\mathrm{t}}=5,638$ & 34 \\
5 & Taflan & $\mathrm{S}_{\mathrm{t}}=3,301$ & 20 \\
6 & Dereköy & $\mathrm{S}_{\mathrm{t}}=2,611$ & 16 \\
7 & Ondokuz Mayıs & $\mathrm{S}_{\mathrm{t}}=8,928$ & 53 \\
8 & Geyikkoşan (Alaçam) & $\mathrm{S}_{\mathrm{t}}=11,950$ & 71 \\
& Total & $\mathrm{T}_{\mathrm{m}}=84,052$ & $\mathrm{Ss}=500$ \\
\hline
\end{tabular}

The questionnaire was prepared in Turkish language, and residents and beach users 18 years of age and older were surveyed in face-to-face interviews. Each questionnaire took about five minutes to com- 


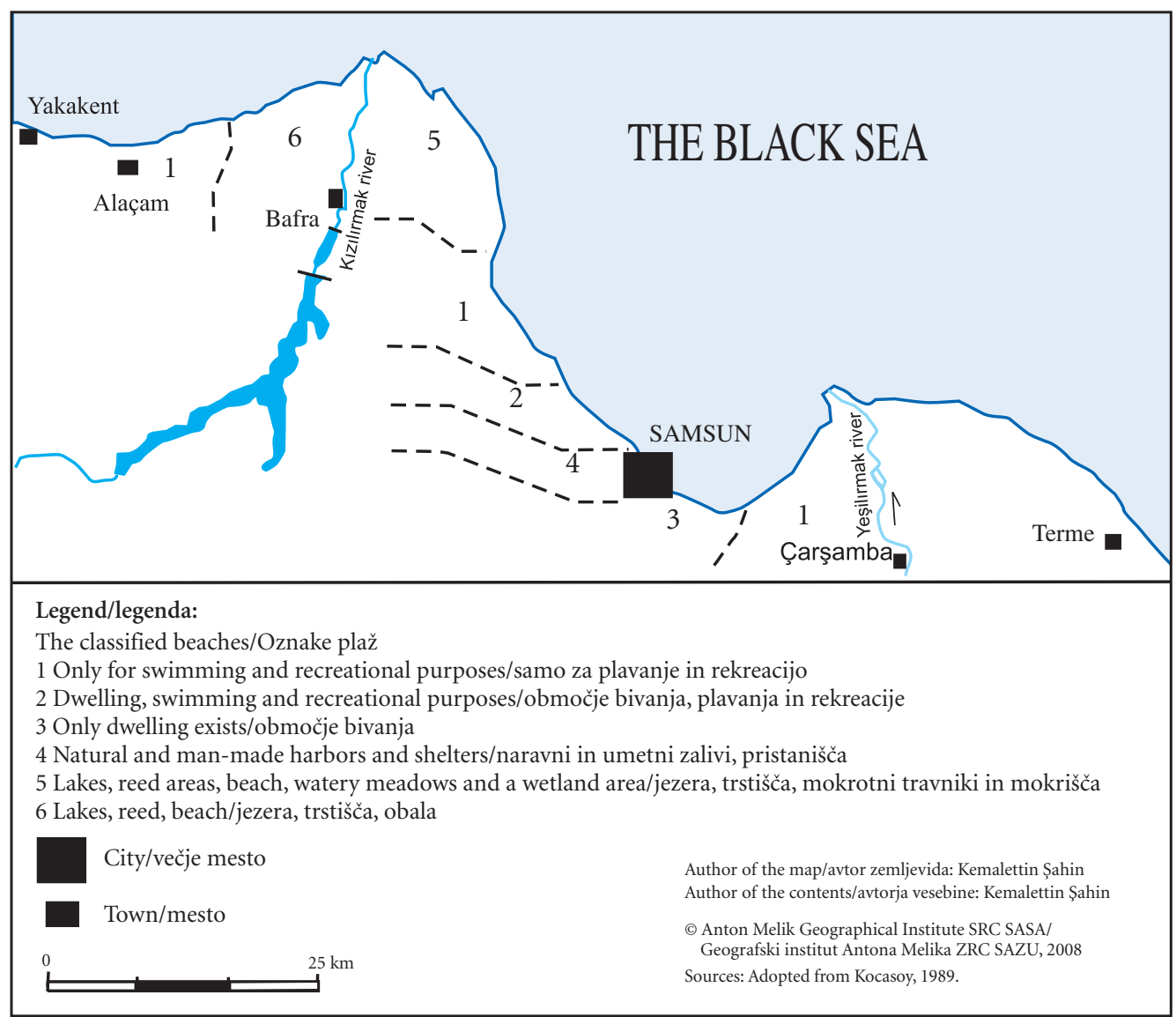

Figure 2: Classified beaches and their boundaries in the area studied (adopted from Kocasoy 1989b). Key: 1. Only for swimming and recreational purposes, 2. dwelling, swimming, and recreational purposes, 3. only dwellings exist, 4. natural and man-made harbours and shelters.

plete. In total, 500 completed surveys were returned for statistical analysis by August 2006. Survey responses were coded for statistical analysis using the Statistical Package for the Social Sciences (SPSS) software. In addition, the beaches in the study area were mapped according to their use (Figure 2).

\section{Results}

Survey participants were composed of $76 \%$ male and $24 \%$ female respondents. The age breakdown of respondents is given in Figure 3. Fifty percent were between the ages of 24 and 35. Most were secondary school graduates (59\%), followed by university graduates (16\%) (Figure 4 ). A large number of tradesmen also appeared in the surveys (34\%), followed by office workers (26\%) (Figure 5).

Respondents were also asked, »What do you think is the most important environmental issue facing the coastal zone today? « Roughly nine out of ten respondents (89\%) put pollution of the coastal seawater in first place, and $66.7 \%$ gave beach pollution, loss of beach plain, and lack of maintenance of the beach as a major problem as their second choice, followed by changes in land use, inadequate drainage, and ownerless dogs near or on the beach (Table 2). 


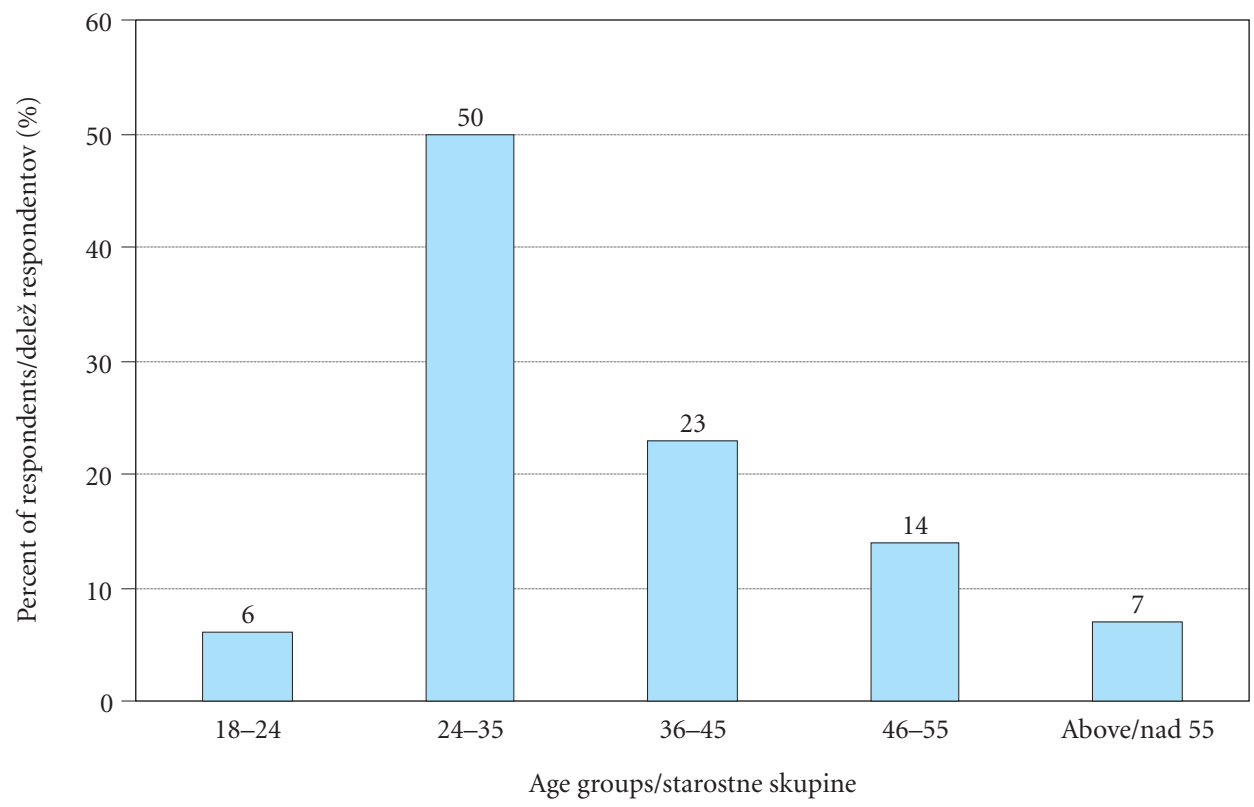

Figure 3: Age distribution of respondents.

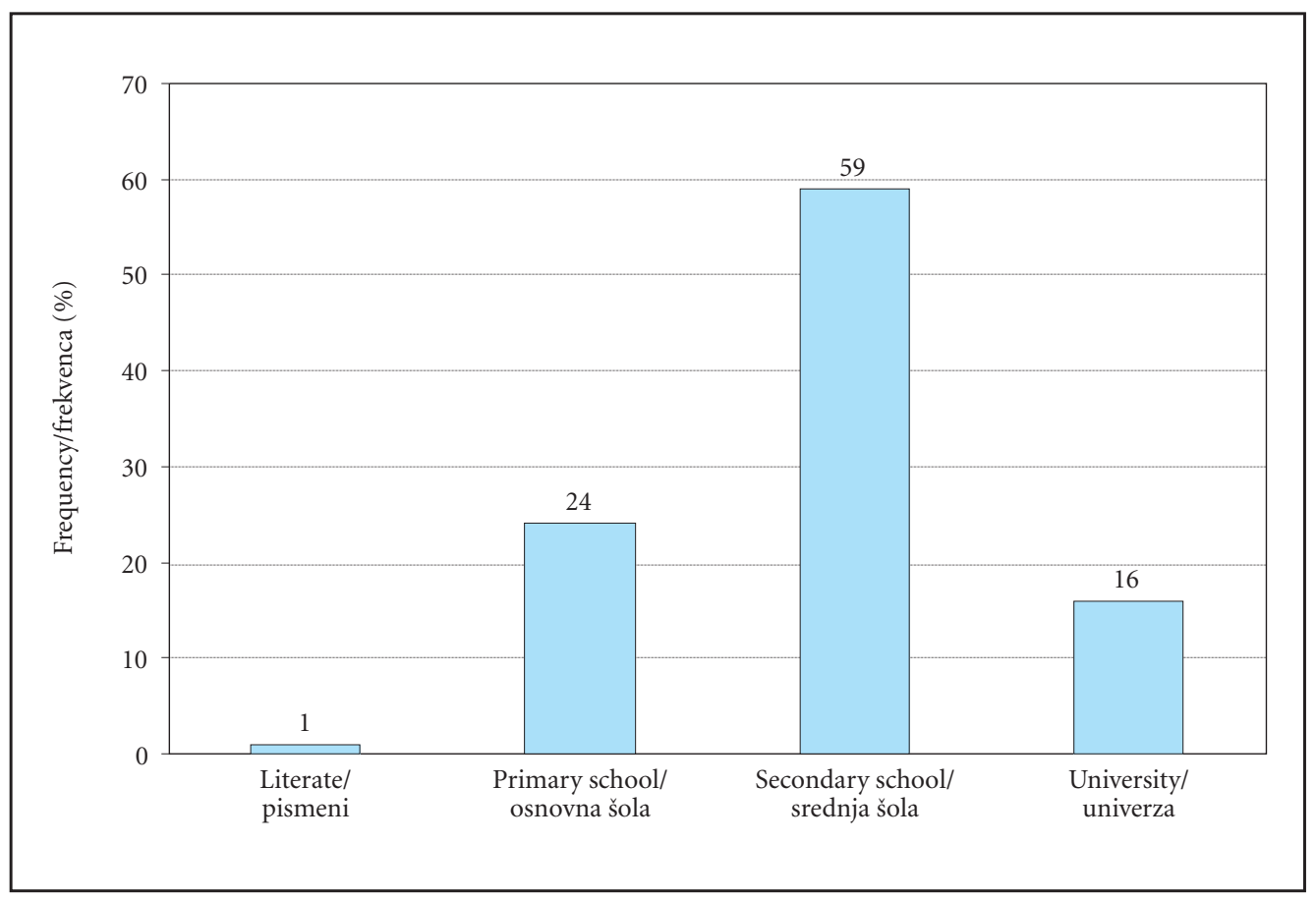

Figure 4: Education level of respondents. 


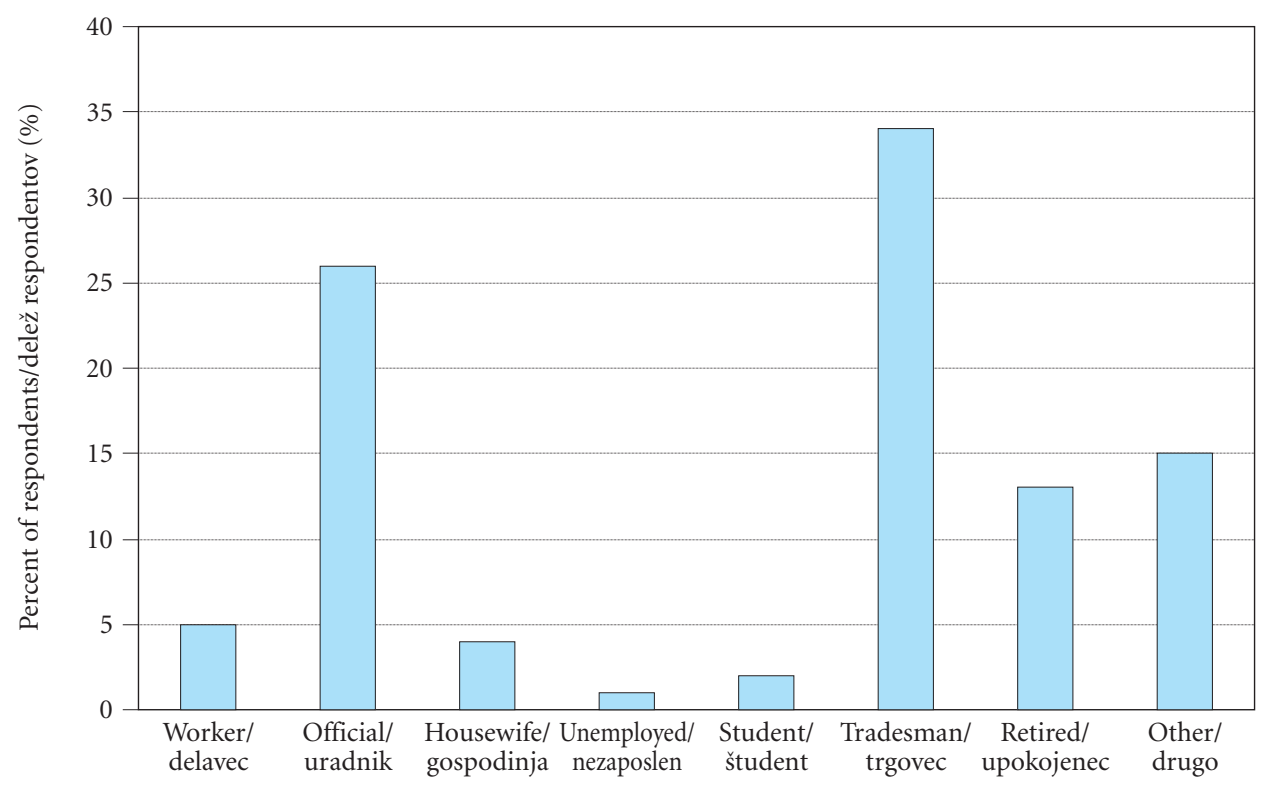

Figure 5: Professions of household heads and beach users.

Table 2: The most important coastal zone environmental problem in this area from the perspective of residents and beach users.

\begin{tabular}{|c|c|c|c|c|c|c|}
\hline \multirow[t]{2}{*}{ Problems } & \multicolumn{2}{|c|}{$1^{\text {st }}$ Choice } & \multicolumn{2}{|c|}{$2^{\text {nd }}$ Choice } & \multicolumn{2}{|c|}{$3^{\text {rd }}$ Choice } \\
\hline & Frequency (\%) & Valid (\%) & Frequency (\%) & Valid (\%) & Frequency (\%) & Valid (\%) \\
\hline Seawater pollution in the coastal zone & 89 & 89 & - & - & 1 & 1.5 \\
\hline $\begin{array}{l}\text { Beach pollution, loss of beach plain, } \\
\text { and lack of beach maintenance }\end{array}$ & 7 & 7 & 62 & 66.7 & - & - \\
\hline Land use changes & 4 & 4 & 25 & 26.9 & 60 & 90.9 \\
\hline Inadequate drainage & - & - & 6 & 6.4 & 1 & 1.5 \\
\hline Ownerless dogs & - & - & - & - & 4 & 6.1 \\
\hline No idea & - & - & 7 & - & 34 & - \\
\hline Total & 100 & 100 & 100 & 100 & 100 & 100 \\
\hline
\end{tabular}

$\mathrm{N}=500,16$ at Çınarlık, 260 at Atakum, 30 at Atakent, 34 at Incesu, 20 at Taflan, 16 at Dereköy, 53 at Ondokuzmayıs, and 71 at Geyikkoşan.

Table 3: What is an important source of coastal seawater pollution.

\begin{tabular}{|c|c|c|c|c|c|c|}
\hline \multirow[t]{2}{*}{ Causes of pollution } & \multicolumn{2}{|c|}{$1^{\text {st }}$ Choice } & \multicolumn{2}{|c|}{$2^{\text {nd }}$ Choice } & \multicolumn{2}{|c|}{$3^{\text {rd }}$ Choice } \\
\hline & Frequency (\%) & Valid (\%) & Frequency (\%) & Valid (\%) & Frequency (\%) & Valid (\%) \\
\hline Sewage & 97 & 98 & 1 & 1.3 & 1 & 2.1 \\
\hline Industrial waste & 1 & 1 & 59 & 73.8 & - & - \\
\hline Mobile power plant & - & - & 5 & 6.3 & 12 & 25.5 \\
\hline Materials brought by rivers & - & - & 9 & 11.3 & 9 & 19.1 \\
\hline Waste oils discharged by ships & - & - & 5 & 6.3 & 18 & 38.3 \\
\hline Heavy rain & 1 & 1 & 1 & 1.3 & 7 & 14.9 \\
\hline No idea & 1 & & 20 & - & 53 & - \\
\hline Total & 100 & 100 & 100 & 100 & 100 & 100 \\
\hline
\end{tabular}

Sewage is the most widespread source of pollution in Samsun along the Black Sea coast. On the question concerning the causes of seawater pollution in the coastal zone, almost all of the respondents (98\%) 
gave »sewage « as the first choice, $78.3 \%$ respondents gave industrial waste waters as the second choice, and all kinds of wastes dumped by ships is in first place (38.3\%) as the third choice. Table 3 summarizes the results of the public's perception of coastal zone problems and current issues.

Respondents were asked whether they thought coastal zone problems had grown worse, remained the same, or improved over the last five years. Over half of the respondents $(51.1 \%)$ stated that the beach is subject to permanent sand and beach plain loss every year due to various causes (natural, anthropogenic) and that the existing beach is neglected, $37.6 \%$ of respondents said the presence of ownerless dogs had gotten better, and $52.6 \%$ said stream, river, and seawater quality was the same.

Table 4: Are the coastal zone problems in your area better, the same, or worse than they were five years ago?

\begin{tabular}{|c|c|c|c|c|c|c|c|c|}
\hline \multirow[t]{2}{*}{ Coastal zone problems } & \multicolumn{2}{|c|}{ Worse } & \multicolumn{2}{|c|}{ The same } & \multicolumn{2}{|c|}{ Better } & \multirow[t]{2}{*}{ No answer (\%) } & \multirow[t]{2}{*}{ Total } \\
\hline & Frequency (\%) & Valid (\%) & Frequency (\%) & Valid (\%) & Frequency (\%) & Valid (\%) & & \\
\hline $\begin{array}{l}\text { Stream, river, and } \\
\text { seawater quality }\end{array}$ & 32 & 33.7 & 50 & 52.6 & 13 & 13.7 & 5 & 100 \\
\hline $\begin{array}{l}\text { Waste materials produced in } \\
\text { industrial and business zones }\end{array}$ & 42 & 45.7 & 38 & 41.3 & 12 & 13.0 & 8 & 100 \\
\hline $\begin{array}{l}\text { Collection of waste material } \\
\text { and recycling processes }\end{array}$ & 17 & 18.3 & 48 & 51.6 & 28 & 30.1 & 7 & 100 \\
\hline $\begin{array}{l}\text { Loss of beach plain and lack } \\
\text { of beach maintenance }\end{array}$ & 46 & 51.1 & 31 & 34.4 & 13 & 14.4 & 10 & 100 \\
\hline Ownerless dogs & 15 & 16.1 & 43 & 46.2 & 35 & 37.6 & 7 & 100 \\
\hline
\end{tabular}

Table 5: The most important coastal zone problems that have worsened in the last five years.

\begin{tabular}{|c|c|c|c|c|c|c|}
\hline \multirow[t]{2}{*}{ Coastal problems } & \multicolumn{2}{|c|}{$1^{\text {st }}$ Choice } & \multicolumn{2}{|c|}{$2^{\text {nd }}$ Choice } & \multicolumn{2}{|c|}{$3^{\text {rd }}$ Choice } \\
\hline & Frequency (\%) & Valid (\%) & Frequency (\%) & Valid (\%) & Frequency (\%) & Valid (\%) \\
\hline Garbage-litter & 22 & 22 & 26 & 29.5 & 1 & 1.7 \\
\hline Pollution of coastal seawater & 29 & 29 & 31 & 35.3 & 8 & 13.3 \\
\hline $\begin{array}{l}\text { Beach pollution, loss of beach plain, } \\
\text { and lack of maintenance }\end{array}$ & 37 & 37 & 24 & 27.3 & 17 & 28.3 \\
\hline Land use change & 12 & 12 & 7 & 7.9 & 34 & 56.7 \\
\hline No idea & - & - & 12 & - & 40 & - \\
\hline Total & 100 & 100 & 100 & 100 & 100 & 100 \\
\hline
\end{tabular}

Table 6: Individual activities engaged in by respondents for the conservation of the coastal zone.

\begin{tabular}{|c|c|c|c|c|c|c|}
\hline \multirow[t]{2}{*}{ Activities } & \multicolumn{2}{|c|}{$1^{\text {st }}$ Choice } & \multicolumn{2}{|c|}{$2^{\text {nd }}$ Choice } & \multicolumn{2}{|c|}{$3^{\text {rd }}$ Choice } \\
\hline & Frequency (\%) & Valid (\%) & Frequency (\%) & Valid (\%) & Frequency (\%) & Valid (\%) \\
\hline $\begin{array}{l}\text { Attending meetings on environmental } \\
\text { issues }\end{array}$ & 32 & 39 & - & - & 2 & 6.3 \\
\hline $\begin{array}{l}\text { Making applications to official } \\
\text { establishments }\end{array}$ & 10 & 12.2 & 17 & 30.4 & - & - \\
\hline $\begin{array}{l}\text { Sending letters to a local or national } \\
\text { newspaper }\end{array}$ & 2 & 2.4 & 5 & 8.9 & 5 & 15.6 \\
\hline $\begin{array}{l}\text { Sending letters to local administrators } \\
\text { or official establishments }\end{array}$ & - & - & 6 & 10.7 & 1 & 3.1 \\
\hline $\begin{array}{l}\text { Warning others about keeping } \\
\text { the beach clean }\end{array}$ & 22 & 26.8 & 12 & 21.4 & 10 & 31.3 \\
\hline $\begin{array}{l}\text { Collecting waste material } \\
\text { on the beach }\end{array}$ & 6 & 7.3 & 6 & 10.7 & 9 & 28.1 \\
\hline Using recyclable materials at home & 10 & 12.2 & 10 & 17.9 & 5 & 15.6 \\
\hline No idea & 18 & - & 44 & - & 68 & - \\
\hline Total & 100 & 100 & 100 & 100 & 100 & 100 \\
\hline
\end{tabular}

A related question asked which of the most important coastal zone problems had grown in the last five years. $37 \%$ of respondents said that beach pollution, loss of beach plain, and lack of maintenance com- 
prised the most important problem, while $22 \%$ of beach users think that garbage-litter is the most important coastal problems that has increased in the last five years (Table 5).

Relative to individual activities done for the conservation of the coastal zone environment, $39 \%$ of respondents had attended meetings on environmental issues, $18 \%$ of survey participants made no statement in the first choice for individual activities, while $44 \%$ in the second choice and $68 \%$ in the third choice made no statements. This situation reveals that beach users and residents are insufficiently aware of issues regarding the conservation of the coastal environment.

Table 7 indicates that most of the respondents have positive opinions regarding the conservation and control of the coastal zone.

Table 7: Opinions about the conservation and control of the coastal zone.

\begin{tabular}{lccccc}
\hline Opinions & DA (\%) & A (\%) & DD (\%) & NI (\%) & T(\%) \\
\hline Environmental protection must be implemented with laws & 62 & 25 & 4 & 9 & 100 \\
Everyone should make changes they want on their own property & 24 & 29 & 35 & 12 & 100 \\
Coastal zone should be conserved properly & 44 & 25 & 21 & 10 & 100 \\
Construction and other infrastructure projects that threaten the coastal zone & 44 & 39 & 7 & 10 & 100 \\
$\quad \begin{array}{l}\text { environment should be blocked } \\
\text { Local municipalities should keep under control any interventions harmful } \\
\quad \text { to the coastal zone environment }\end{array}$ & 52 & 34 & 4 & 10 & 100 \\
\hline
\end{tabular}

Explanation: DA, Definitely Approve; A, Approve; DD, Definitely Disapprove; NI, No idea; T, Total.

Finally, the respondents were asked to prioritize their choice of suggestions for preventing coastal seawater and beach pollution. Dumping sewage in the sea only after treatment received $1^{\text {st }}$ priority $(70.7 \%)$, building treatment facilities for industries received $2^{\text {nd }}$ priority $(46.9 \%)$, and implementing punishments (laws-regulations) concerning environmental protection effectively on everyone received $3^{\text {rd }}$ priority (38\%). The fact that no participant listed the suggestion of public and nongovernmental organizations (NGOs) providing educational activities to develop environmental awareness such as meetings, workshops, courses, and posters as a first priority indicates that the respondents do not consider education important for developing environmental awareness.

Table 8: Suggestions for preventing coastal seawater and beach pollution.

\begin{tabular}{|c|c|c|c|c|c|c|}
\hline \multirow[t]{2}{*}{ Suggestions } & \multicolumn{2}{|c|}{$1^{\text {st }}$ priority } & \multicolumn{2}{|c|}{$2^{\text {nd }}$ priority } & \multicolumn{2}{|c|}{$3^{\text {rd }}$ priority } \\
\hline & Frequency (\%) & Valid (\%) & Frequency (\%) & Valid (\%) & Frequency (\%) & Valid (\%) \\
\hline $\begin{array}{l}\text { Sewage should be discharged in the sea } \\
\text { only after treatment }\end{array}$ & 70 & 70.7 & 4 & 4.2 & 1 & 1.3 \\
\hline $\begin{array}{l}\text { Building treatment facilities for industrial } \\
\text { enterprises }\end{array}$ & 18 & 18.2 & 45 & 46.9 & 3 & 3.8 \\
\hline $\begin{array}{l}\text { Collection of household wastes } \\
\text { and litter at certain times of the day }\end{array}$ & 6 & 6.1 & 16 & 16.7 & 16 & 20.3 \\
\hline $\begin{array}{l}\text { Reporting persons or establishments } \\
\text { that cause pollution to the authorities }\end{array}$ & 4 & 4 & 20 & 20.8 & 6 & 7.5 \\
\hline $\begin{array}{l}\text { Public institutions and NGOs providing } \\
\text { educational activities that develop } \\
\text { environmental awareness such } \\
\text { as meetings, workshops, courses, } \\
\text { posters }\end{array}$ & - & - & 8 & 8.3 & 23 & 29.1 \\
\hline $\begin{array}{l}\text { Implementation of punishments } \\
\text { concerning environmental protection } \\
\text { effectively on everyone }\end{array}$ & 1 & 1 & 3 & 3.1 & 30 & 38 \\
\hline No idea & 1 & - & 4 & - & 21 & - \\
\hline Total & 100 & 100 & 100 & 100 & 100 & 100 \\
\hline
\end{tabular}




\section{Discussion}

Public perceptions of and opinions on coastal zone issues as a regional problem are significantly exposed by this study. In the studied area, $89 \%$ of the residents and beach users name coastal seawater pollution in first place as the main coastal zone problems, $7 \%$ of the respondents name beach pollution, loss of beach plain, and lack of maintenance of beaches, and only $4 \%$ of the respondents name changes in land use (rapid urbanization, secondary houses, transportation roads; Table 2).

Beach pollution, loss of beach plain, and lack of maintenance of beaches could have been named at a higher rate by respondents. The coastal erosion is obvious in this area, and shoreline erosion of delta plains (Çarşamba and Bafra), greatly accelerated by human structures, has already threatened beach boundaries in Samsun's coastal zone (Uzun 2006). The other causes of loss of beach plain are natural conditions (currents and coastal erosion), anthropogenic factors (dams built on the Yeşilırmak and Kızılırmak rivers, walking paths and car roads, children's parks, tea gardens, illegal sand quarrying), and the current neglect of beaches. Illegal beach sand quarrying has continued at the Geyikkoşan beach in recent years (Uzun 2005). Şahin (2005a, 109) explains also that beach sand loss occurs every year in Turkey due to use in construction. It is understood that this is a general problem for Turkey, but many survey respondents clearly did not perceive it as a serious problem.

As important coastal problems that have continued to worsen in the last five years, beach pollution, loss of beach plain, and the lack of maintenance (37\%), coastal seawater pollution (29\%), and garbage-litter $(22 \%)$ appear as first choices. Garbage-litter is a major coastal zone problem and is a critical problem in the studied area. Small fragments of plastic, cigarette butts, and other organic and inorganic matter are the most abundant residues found after sunset. The Atakum municipality, where beach use pressures are high, therefore conducts a daily evening cleanup of the beach employing a special tractor during the summer. Santos et al. (2005) showed that there are strong correlations between beach visitor density and litter generation. In fact, litter in the oceans and along the coasts of world has become a problem of great proportions (Hartwig et al. 2007). Long-term waste recording projects along Germany's North Sea coast have shown an average plastic content of $62.5 \%$ in beach-washed garbage (Hartwig et al. 2007).

Land use, a subject of applied geography, refers to the various ways in which human beings make use of and manage the land and its resources. The Atakum and Atakent settlements that have grown steadily in the last ten years, the widening of transportation roads, the coastal road whose construction continues by incorporating a part of the beach, and constructions such as parks and children's playgrounds on land reclaimed from the sea, and seaside cafes are noticeable as important coastal zone problems. On the other hand, few respondents - only $4 \%$ ! - pointed out this problem. İrtem et al. $(2005,37)$ emphasize that »the coastal zone in most countries has been subjected to severe and increasing pressure as a result of conflicting uses such as rapid urbanization, environmental pollution, tourism development, and other coastal activities." Continuing coastal urbanization and the consequent replacement of natural vegetation with impervious surfaces will increase stormwater runoff and the discharge of numerous pollutants into coastal waters (Malin et al. 2001).

Almost all the respondents indicated that they consider sewage the most important source of seawater pollution in the coastal zone. Population growth and tourism activities can be directly linked to the problem of sewage. However, other agents also pollute the seawater and the beach. Santos et al. $(2005,743)$ observe that "marine debris are any manufactured or processed solid waste material that enters the marine environment from any source. The four main sources of marine and coastal litter are recreational and tourism-related litter, fishing debris, sewage-related debris, and shipping waste." In the oceans, the threat to marine life comes in various forms such as overexploitation and harvesting, dumping of waste, pollution, alien species, land reclamation, dredging, and global climate change and one particular form of human impact constitutes a major threat to marine life: the pollution by plastic debris (Derraik 2002). Santos et al. $(2005,745)$ mention a questionnaire survey regarding the southern Brazilian coastal ecosystem in which nearly $54 \%$ of answers to the question »What is the worst beach you have visited and why? were linked to litter, sewage, and polluted water and/or sand. Although the »legal aspect of illegal pollution of the shores and oceans of the world by debris, plastic in particular, with vast damage to marine life is clear " (Hartwig et al. 2007, 597), respondents did not mention this as one of the causes of coastal seawater pollution even though litter and debris such as plastic, metal, glass, beer and soft drink bottles, 
toothbrushes, shampoo and deodorant containers, sewage-derived items, cigarette lighters, clothes, shoes, etc. were observable on all the beaches where the survey was taken.

Coastal seawater is polluted especially by sewage waste waters and can cause serious health problems (Edwin, Geldreich 1975; Langford et al. 2000). Water polluted by sewage can be the cause of various ailments (headaches, vomiting, diarrhea, typhoid fever, bacteria, anaerobic dysentery, etc.) caused by pathogens or microorganisms (Daby et al. 2002). Sea pollution in tourist areas away from industrial districts usually takes the form of microbial pollution (Kocasoy 1989a). The discharging of industrial wastes without treatment was placed by $73.8 \%$ of the respondents in second place among the factors that cause coastal problems. Rosalind (2000) observed that the discharge of industrial wastes without treatment affects marine organisms negatively and pollutes coastal waters. The results of our survey are consistent with scientific studies describing the contribution of sewage and industrial wastes to the pollution of coastal seawater.

It is interesting that among the factors that cause coastal seawater pollution, no one cited materials brought by rivers as the first choice. $11.3 \%$ of the respondents only named it as the second choice, and $19.1 \%$ named it as the third choice (Table 3). The Kızılırmak, Yeșilırmak, Kürtün, and Mert rivers and other streams are often degraded by pollutants. These rivers carry discharges and runoff waters from rural area in their watersheds. Land-based sources of pollution include litter left by beach users, litter entering the sea via rivers or municipal drainage systems, and litter and garbage directly deposited on or near the beaches (Williams et al. 2003).

It is a commonly occurring process that the debris littering the Samsun beaches or the coastal seawater has been deposited by rivers during heavy rains. Unlike the longer Kızılırmak and Yeşilırmak rivers, the Kürtün and Mert rivers and other small streams generally originate from heights of 500 to 1,000 meters above sea level and flow into the sea after ten to fifty kilometers, which is a comparatively short distance. Consequently, their speed is fast and after heavy rains they carry solid and liquid wastes along with large amounts of alluvium. This problem is named by only $1 \%$ of the respondents. Another source of seawater pollution referred to by Santos et al. (2005) and Williams et al. (2003) is floating litter that is carried for long distances by currents and can pollute areas far from its source.

Regarding personal involvement in the coastal zone's preservation, 39\% of respondents stated that they attended meetings on environmental zone problems and made applications to local municipalities or official institutions (30.4\%). $31.3 \%$ of respondents stated that they warn others about the cleanliness of beach when they observe people littering. Tudor and Williams (2006) emphasize that cleanliness, recreational aspects, and natural attributes are frequently mentioned in questionnaire responses concerning the important factors of a beach from a beach user's perspective.

Among the suggestions for preventing coastal seawater and beach pollution, it is interesting that no participant named the suggestion of public and non-governmental organizations (NGOs) providing educational activities to develop public awareness of environmental protection such as meetings, workshops, courses, and posters as a first-priority measure against coastal seawater and beach pollution (Table 8). However, along with formal educational institutions, voluntary organizations in which the public participates have an important role in making coastal areas cleaner and more pleasant places to live with the help of printed and other media. A combination of legislation and the enhancement of ecological consciousness through education is likely to be the best way to solve such environmental problems (Derraik 2002).

\section{Conclusion}

This study showed that that public does not have sufficient information on coastal zone problems. Many residents and beach users expect the state, the government, the municipality, or someone else to solve these problems. However, the public is a major component in the solution of problems and the implementation of environmental laws and rules. That there is a great gap between the true problems in the coastal zone and the perceptions of the public is clearly evident from the survey. It generally emerged that coastal zone issues are becoming worse under the impact of human activity in Samsun province. Samsun's beaches and delta areas are at risk of area reduction due to natural (wind, coastal current, granulation of sand) and human factors (construction, new infrastructure, etc.). The use of Samsun's coastal zone has increased every year, but the environmental awareness of people has not accompanied the rise in its use. It is clear that sources of pollution input and their impact on the Black Sea will increase if no preventive actions are taken. 
This research was funded by the University of Ondokuz Mayıs under Project no. F346.

The author wishes to thank Associate Professor Dr. Mehmet Ali Cengiz and Associate Professor Dr. Vedat Sağlam for their technical statistical methods and advice.

\section{References}

Baysan, K. S. 2001: Perceptions of the Environmental impacts of Tourism:a comparative study of the attitudes of German, Russian and Turkish tourists in Kemer, Antalya. Tourism Geographies 3. Oxford. doi: 10.1080/14616680010030284

Buttimore, M. 2004: Environmental Awareness Survey. Report. İnternet:

http://www.hauraki-dc.govt.nz/documents/minutes/Committees/Planning_and_Finance/2004/June/ EnvironAwareness.pdf (1.6.2004).

Daby, D., Turner, J., Jago, C. 2002: Microbial and nutrient pollution of coastal bathing waters in Mauritius. Environment International 27. Amsterdam. doi: 10.1016/S0160-4120(01)00109-X

Derraik, J. G. B. 2002: The pollution of marine environment by plastic debris: a review. Marine Pollution Bulletin 44. Amsterdam. doi:10.1016/S0025-326X(02)00220-5

Edwin, E., Geldreich, E. E. 1975: Microbiological criteria concepts for coastal bathing waters. Ocean Management 2. Amsterdam. doi:10.1016/0302-184X(75)90003-7

Hartwig, E., Clemens, T., Heckroth, M. 2007: Plastic debris as nesting material in a Kittiwake-(Rissa tridactyla)-colony at the Jammerbugt, Northwest Denmark. Marine Pollution Bulletin 54. Amsterdam. doi:10.1016/j.marpolbul.2007.01.027

Internet 1: http://www.turkstat.gov.tr/Start.do (24. 6. 2004).

Irtem, E., Kabdasl1, S., Azbar, N. 2005: Coastal Zone Problems and Environmental Strategies to be Implemented at Edremit Bay, Turkey. Environmental Management 36. Springer. New York. doi:10.1007/ s00267-004-0062-5

Kocasoy, G. 1989a: The relationship between coastal tourism, sea pollution and public health: A case study from Turkey. The Environmentalist 9. Springer. New York. doi:10.1007/BF02241824

Kocasoy, G. 1989b: Method for Prediction of Extent of Microbial Pollution of Seawater and Carrying Capacity of Beaches. Environmental Management 13. New York. doi: 10.1007/BF01867680

Langford, I. H., Georgiou, S., Bateman, I. J., Day, R. J., Turner, R. K. 2000: Public Perceptions of Health Risks from Polluted Coastal Bathing Waters: A Mixed Methodological Analysis Using Cultural Theory. Risk Analysis 20. Oxford. doi:10.1111/0272-4332.205062

Malavasi, U. C. Malavasi, M. M. 2004: Awareness of a conservation unit: a Brazilian case study. Journal for Nature Conservation 12. Amsterdam. doi:10.1016/j.jnc.2003.08.004

Malin, M. A., Ensign, S. H., McIver, M. R., Shank, G. C., Fowler, P. K. 2001: Demographic, landscape, and meteorological factors controlling the microbial pollution of coastal waters. Hydrobiologia 460. Amsterdam. doi:10.1023/A:1013169401211

Mcbride, G. B., Salmond, C. E., Bandaranayake, D. R., Turner, S. J., Lew1s, G. D., Till, D. G. 1998: Health effects of marine bathing in New Zealand. International Journal of Environmental Health Research 8. Abingdon. doi: 10.1080/09603129873462

Mensah, J. V. 1997: Causes and effects of coastal sand mining in Ghana. Singapore Journal of Tropical Geography 18. Oxford. doi:10.1111/1467-9493.00005

Morgan, R., Gatell, E., Junyent, R., Micallef, A., Özhan, E. Williams, A. T. 2000: An improved user-based beach climate index. Journal of Coastal Conservation 6. Amsterdam. DOI 10.1007/BF02730466.

Nelson, C., Botterill, D. 2002: Evaluating the contribution of beach quality awards to the local tourism industry in Wales - the Green Coast Award. Ocean \& Coastal Management 45. Amsterdam. doi:10.1016/ S0964-5691(02)00053-4

Nişanc1, A. 1989: An important periods towards the seasonal weather types in the Middle Black Sea Region. The Geographical Researchs, Atatürk Culture, Literature and History Higher Institution, Geography Science and Application Department I. Ankara.

Nordstrom, K. F., Mitteager, W. A. 2001: Perceptions of the value of natural and restored beach and dune characteristics by high school students in New Jersey, USA. Ocean \& Coastal Management 44. Amsterdam. doi:10.1016/S0964-5691(01)00065-5 
Pendleton, L. Martin, N., Webster, D. G. 2001: Public Perceptions of Environmental Quality:A Survey Study of Beach Use and Perceptions in Los Angeles County. Marine Pollution Bulletin 42. Amsterdam. doi: 10.1016/S0025-326X(01)00131-X

Rosalind, M. R. 2000: Ecoepidemiology of the effects of pollution on reproduction and survival of early life stages in teleosts. Fish and Fisheries 1. Oxford. doi: 10.1046/j.1467-2979.2000.00006.x

Santos, I. R., Friedrich, A. C., Kersanach, M. W., Fillmann, G. 2005: Influence of socio-economic characteristics of beach users on litter generation. Ocean \& Coastal Management 48. Amsterdam. doi:10.1016/ j.ocecoaman.2005.08.006

Şahin, C. 2005a: The Physical Geography of Turkey, Gündüz Eğitim ve Yayıncılık. Ankara.

Şahin, K. 2005b: Ripple Marks formation and interaction with climatic parameters in the Black Sea coastal: Atakum (Samsun) sample. Turkish Geography Society 44. İstanbul.

Smrekar, A. 2006: From drawing cognitive maps to knowing the protection zones for drinking water resources. Acta geographica Slovenica 46-1. Ljubljana. doi: 10.3986/AGS46101

Tudor, D. T., Williams, A. T. 2006: A rationale for beach selection by the public on the coast of Wales, UK. Area 38. Chicester. doi:10.1111/j.1475-4762.2006.00684.x

Tzatzanis, M., Wrbka, T., Sauberer, N. 2003: Landscape and vegetation responses to human impact in sandy coasts of Western Crete, Greece. Journal for Nature Conservation 11. Amsterdam. doi:10.1078/16171381-00047

Uzun, A. 2005: Samsun İli Kıyılarında Antropojenik Değişmeler. Internet: http://www.eies.itu.edu.tr/ TURQUA/pdf/turqua5/TurquaV_183-190_Uzun.pdf (16.5.2006).

Uzun, A. 2006: Samsun Deltaları ve Beklenen Değişmeler. Internet: http://www.samsun.bel.tr/hizmet_ birimleri/kulturwebsite/samsem2006/doc/031.pdf (3.2.2007).

Yalçıner, A. C., Gökdalay, M. 2000: Marine Parks for protection and tourism in Turkey. Journal of Coastal Conservation 6. Amsterdam. doi:10.1007/BF02730468

Williams, A. T., Tudor, D. T., Randerson, P. 2003: Beach Litter Sourcing in the Bristol Channel and Wales, U. K. Water, Air, and Soil Pollution 143. Amsterdam. doi:10.1023/A:1022808908500 



\title{
Zaznavanje okoljskih problemov v javnosti v obalnem območju okrožja Samsun v Turčiji
}

\author{
DOI: $10.3986 / A G S 49207$ \\ UDC: 91:504.5(560.624) \\ COBISS: 1.01
}

IZVLEČEK: V zadnjih desetletjih je človek z različimi dejavnosti vplival na izgled obale v okrožju Samsun in s tem spreminjal celoten obalni pas v tem območju. $V$ tej razpravi sem poskušal ugotoviti, kako prebivalci in uporabniki plaž razumejo in gledajo na okoljske probleme obalnega območja okrožja Samsun. S tem namenom smo v juniju in juliju v letih 2005 in 2006 izvedli anketo na podlagi vprašalnika med 500 prebivalci in uporabniki plaž na osmih plažah okrožja Samsun, ki se raztezajo na $121 \mathrm{~km}$ obale na severu Turčije. Podatke smo zbirali s pomočjo intervjuja. Analiza podatkov iz intervjujev je pokazala, da so anketiranci kot glavni problem obalnega območja opazili onesnaženje obalnih morskih voda (89\%), onesnaženje plaž in izgubo površine plaž (67\%) in spremembe v rabi tal (91\%). Glavni dejavniki onesnaženja obalnih morskih voda so odplake (98\%), industrijski odpadki $(74 \%)$ in odpadna olja, ki jih izpuščajo ladje (38\%). Raziskava med prebivalci in uporabniki plaž je jasno pokazala, da se le-ti ne zavedajo dovolj okoljskih problemov obalnega območja. Da bi rešili te probleme, je nujno potrebno, da se celotna družba začne zavedati okoljskih problemov. Predlagamo, da se uvedejo programi za okoljsko izobraževanje prebivalstva, ki bi pomagali pri ohranjanju ekosistemov obalnega območja.

KLJUČNE BESEDE: geografija, onesnaževanje obale, zaznavanje, javnost, ozaveščanje, odpadne vode, Samsun, Turčija

Uredništvo je prejelo prispevek 18. februarja 2008.

NASLOV:

dr. Kemalettin Şahin

Department of Geography, Faculty of Arts And Science, Ondokuz Mayıs University 55139 Kurupelit, Samsun, Turkey

E-pošta:ksahin@omu.edu.tr

\section{Vsebina}

2 Metodologija 445

2.1 Območja raziskave 445

2.2 Podatki in metode 446

3 Rezultati 447

4 Razprava 450

5 Sklep 452

6 Literatura 452 


\section{Uvod}

V zadnjih petih do desetih letih je degradacija morja v obalnem območju okrožja Samsun postala resen in pomemben problem. Na območju naše raziskave se izvajajo rekreativne dejavnosti, posegi v prostor in urbanizacija, na nekaterih plažah pa celo izkopavajo pesek za gradnjo. Obalno območje so precej prizadeli krčenje naravnega okolja in izgradnja infrastrukture, na primer izgradnja bivalnih objektov, objektov za transport, odvajanje odpadnih voda, izgradnja sistema za preskrbo z vodo, postopki za pridobitev zemljišč in vodni parki. Velik problem pri onesnaženju plaž v Samsunu predstavljajo tudi smeti in trdni odpadki. Morgan in ostali (2000) poudarjajo, da je Samsun majhna turistična destinacija za turiste iz severne Evrope, ki se sooča s problemi zaradi neustrezne infrastrukture in onesnaženja. V Turčiji degradacija okolja in obalnega območja predstavlja resen problem (İrtem in ostali 2005). Nekatere znanstvene študije obravnavajo prav onesnaženje plaž in morja z odpadki v različnih delih sveta (Derraik 2002; Williams in ostali 2003; Hartwig in ostali 2007).

Turčijo obkrožajo Črno morje, Marmarsko morje, Egejsko morje in vzhodno Sredozemsko morje. Obalna območja teh morij imajo zelo raznolike naravne in kulturne vrednote (Yalçıner in Gökdalay 2000). Na teh obalnih območjih se izvajajo različne ekonomske in rekreativne dejavnosti, posledica pa so možnosti zlorabe, onesnaženje in neurejena urbanizacija zaradi prenaseljenosti (Mensah 1997; Morgan in ostali 2000; Tzatzanis in ostali 2003; İrtem in ostali 2005). V literaturi se velikokrat navaja potreba po zaščiti obalnih morskih voda in obal kot občutljivih ekosistemov (Mensah 1997; İrtem in ostali 2005). Plaže so pomembne naravne znamenitosti, ki jih za počitek, zabavo in sprostitev uporabljajo tako prebivalci kot tudi turisti (Tzatzanis in ostali 2003; Tudor in Williams 2006). V nekaterih anketnih študijah sprašujejo uporabnike plaž o tem, kaj menijo o uporabi, izrabi in zaščiti plaž in kaj javnost misli o onesnaženju obalnih voda (Kocasoy 1989a; Mcbride in ostali 1998; Baysan 2001; Nordstrom in Mitteager 2001; Pendleton in ostali 2001; Nelson in Botterill 2002; Malavasi in ostali 2004; Santos in ostali 2005; Smrekar 2006; Tudor in Williams 2006).

Okrožje Samsun se ponaša s širokimi in dolgimi plažami, ki obsegajo 213 km obale. Poleg geomorfoloških značilnosti je razlog za nastanek teh plaž tudi učinek reke Kızılırmak, ki je najdaljša turška reka $(1355 \mathrm{~km})$, ter reke Yeşilırmak $(519 \mathrm{~km})$ in desetine manjših potokov, ki se na območju te province izlivajo v Črno morje. Plaže v Samsunu so iz drobnozrnatega peska. Ležijo med vznožjem gore Canik in Črnim morjem. Granulacija peska na plaži na območju študije je srednje do drobnozrnata. Po Wentworthovi klasifikaciji imajo zrna premer med 0,0625 mm in $1 \mathrm{~mm}$ (Şahin 2005b). Na nekatrerih mestih širina plaž doseže $50 \mathrm{~m}$.

Namen te študije je:

- raziskatati razlike v zaznavanju in mnenju prebivalcev in uporabnikov plaž glede onesnaženja plaž in obalnih morskih voda;

- preveriti okoljske probleme obalnega območja in vzroke zanje na različnih predelih plaž, ki jih uporabljajo kopalci;

- dvigniti raven ozaveščenosti javnosti o okoljskih problemih obalnega območja in

- določiti posamezne ukrepe, da se plaže in obalnih morskih voda zaščitijo pred onesnaženjem.

Drugi namen te raziskave je prispevati k oblikovanju politike nacionalnega in regionalnega razvoja obalnega območja. Raziskave o tem, kako javnost gleda na plaže v Samsungu, ne zadostujejo, zato smo za razliko od drugih člankov pri tej študiji uporabili drugačne metode.

\section{Metodologija}

\subsection{Območje raziskave}

Območje raziskave leži približno med $41^{\circ} 27^{\prime}$ in $41^{\circ} 74^{\prime}$ severne zemljepisne širine ter med $35^{\circ} 54^{\prime}$ in $36^{\circ} 53^{\prime}$ vzhodne zemljepisne dolžine oziroma v okolici Samsun. Obale Črnega morja na severu Turčije ležijo v bližini gora, ki se strmo spuščajo proti morju. Obala v Samsunu je v glavnem nizka (plaže), zato delti rek Kızılırmak in Yeşilırmak ležita v provinci Samsun (Uzun 2005, 183). Območje raziskave se začenja na vzhodu na plaži Costal blizu mesta Çınarlık v okolici mesta Çarşamba in se nadaljuje vzdolž $121 \mathrm{~km}$ obale z nekaj prekinitvami do obale Yakakent na zahodu (Slika 1). 
Topografijo določajo plaža, obalna ravnica, pobočja in gore. Večina naselij in prebivalstva leži ob obali, pod 100 m nadmorske višine. Okolica Samsuna leži v obalnem območju in ima »vlažno-zmernotoplo podnebje « oziroma črnomorsko podnebje. Povprečna letna temperatura znaša $14,3^{\circ} \mathrm{C}$ in je brez večjih letnih temperaturnih nihanj (Nișanc1 1989). Morgan in ostali $(2000,48)$ ugotavljajo, da je: »... za podnebje Črnomorske obale (je) značilen »hladen « toplotni občutek na začetku sezone. Na višku sezone (od julija do septembra) ima Samsun odlično podnebje za turizem na plaži in skoraj idealno temperaturo vode za kopanje in prijeten toplotni občutek, še posebej za turiste iz severne Evrope...«.

V kopalni sezoni (od srede junija do konca avgusta) je območje raziskave pod intenzivnim pritiskom lokalnih prebivalcev in obiskovalcev iz okoliških krajev. Območje ob plažah ima približno 90.000 stalnih prebivalcev, v poletnih mesecih pa se zaradi uporabnikov plaž njihovo število poveča tudi za petkrat. Center mesta Samsun ima po podatkih iz popisa prebivalstva iz leta 2000 kar 363.180 prebivalcev.

Slika 1: Lokacija plaž, ki je del raziskave. Ključ: 1 - Costal, 2 -Atakum, 3-Atakent, 4-İncesu, 5 -Taflan, 6 - Dereköy, 7 - Ondokuzmayıs, 8 - Geyikkoşan.

Glej angleški del prispevka.

\subsection{Podatki in metode}

Anketa med prebivalci in uporabniki plaž je bila izvedena v mestih in na plažah in sicer poleti leta 2005 in 2006 (Slika 1). Uporabniki plaž so bili v glavnem lokalni prebivalci in izletniki. Anketo smo izvajali dve leti na osmih plažah: »Costal«, »Atakum«, »Atakent«, »Incesu (Altınkum)«, »Taflan«, »Dereköy«, »Ondokuz Mayıs«, »Geyikkoşan (Alaçam)《. Skupno smo intervjuvali 271 zasebnih gospodinjstev in 229 uporabnikov plaž. Intervjuje smo izvajali med 9. in 16. uro, in sicer ob sobotah in nedeljah, ko je bilo na plažah veliko ljudi.

Vprašanja v anketi so temeljila na poizvedbah in opazovanju. Uporabili smo tudi vprašanja iz Buttimore (2004). Uporabljali smo raziskovalne metode, vprašanja in vsebine z Oddelka za statistiko na naši univerzi.

Anketirancem smo zastavili dvanajst vprašanj izbirnega tipa in izbrati so morali eno od več možnosti. Tri vprašanja so obravnavala po socialnih podskupinah, na primer spol, starost, izobrazba in zaposlitev. Sedem vprašanj je obravnavalo presojo, namreč kako anketiranci gledajo na probleme obalnega območja (še posebej problematiko plaž in obalnih morskih voda), zanimale so nas njihovo zavedanje in zaznavanje problema, ideje in prepričanje. Dve vprašanji pa sta obravnavali izkušnje in vedenje anketirancev. Pri anketi smo dajali prednost zaprtemu tipu vprašanj.

Za določitev ciljne množice smo uporabili podatke zadnjega turškega popisa prebivalstva. Demografske podatke (prebivalstvo) je zagotovil Turški inštitut za statistiko (internet 1). Velikost vzorca smo oblikovali zaradi velikosti skupnosti, kjer smo podatke pridobili, in ker se ne da točno ugotoviti števila obiskovalcev plaž. Obiskovalci plaž in prebivalci so tvorili razslojen vzorec prebivalstva, ki uporablja plaže, ki smo ga dobili s pomočjo podatkov iz popisa prebivalstva iz leta 2000. Śtevilo vseh članov ciljne skupine zajetih v raziskavi je bilo 84.052. Opravili smo sto predhodnih intervjujev in določili probleme obalnega območja, ki jih opažajo prebivalci in uporabniki plaž na območju med mestoma Costal in Yakakent. $80 \%$ anketirancev $(\mathrm{P})$ pozitivno razmišlja o problemih obalnega območja (obalna morska voda, onesnaženje plaž, urbanizacija ...), $20 \%$ pa ima negativno mišljenje. Pri rezultatih je stopnja natančnosti $95 \%(\alpha=0,05)$ in 1,96 pri $5 \%$ dovoljenem odstopanju in $95 \%$ stopnji zaupanja. S spodnjo formulo smo ugotovili primerno velikost vzorca.

$\mathrm{N}=\mathrm{Z}^{2} \cdot(\mathrm{P}) \cdot(1-\mathrm{P}) / \mathrm{C}^{2}$

$\mathrm{N}=$ velikost vzorca,

$\mathrm{Z}=$ teoretična vrednost (1,96 pri $95 \%$ stopnjo zaupanja),

$\mathrm{P}=$ verjetnost realizacije, izražena $\mathrm{v}$ decimalkah (uporabili smo 0,80 za potrebno velikost vzorca),

$\mathrm{C}=$ stopnja zaupanja, izražena $\mathrm{v}$ decimalkah $(0,05)$.

$\mathrm{V}$ našem primeru smo $\mathrm{N}$ izračunali, kot sledi:

$\mathrm{N}=(1,96)^{2} \cdot[(0,80) \cdot(1-0,80)] /(0,05)^{2}=3,8416 \cdot 0,16 / 0,0025=0,614656 / 0,0025=245$.

Glede na dejavnost raziskave smo pri velikosti ciljne množice $\mathrm{T}_{\mathrm{m}}=84,052$ dobili velikost vzorca $(\mathrm{SS}=500)$. To vrednost smo porazdelili med območja, kjer smo izvajali anketo, sorazmerno z razslojenim vzorčenjem $\left(S_{t}\right)$ (Preglednica 1). Enačba je naslednja:

$\mathrm{S}=\left(\mathrm{S}_{\mathrm{S}} \cdot \mathrm{S}_{\mathrm{t}}\right) / \mathrm{T}_{\mathrm{m}}$, kjer je

$\mathrm{S}=$ število anket za razslojeno vzorčenje, 
SS $=$ velikost vzorca,

$\mathrm{S}_{\mathrm{t}}=$ razslojeno vzorčenje,

$\mathrm{T}_{\mathrm{m}}=$ ciljna množica.

Preglednica 1: Podatki za posamezno območje.

\begin{tabular}{llcr}
\hline območje & plaže - območja & prebivalstvo (podatki iz popisa leta 2000) & vzorec \\
\hline 1 & Çınarlık & $\mathrm{S}_{\mathrm{t}}=2,655$ & 16 \\
2 & Atakum & $\mathrm{S}_{\mathrm{t}}=43,905$ & 260 \\
3 & Atakent & $\mathrm{S}_{\mathrm{t}}=5,064$ & 30 \\
4 & Incesu (Altınkum) & $\mathrm{S}_{\mathrm{t}}=5,638$ & 34 \\
5 & Taflan & $\mathrm{S}_{\mathrm{t}}=3,301$ & 20 \\
6 & Dereköy & $\mathrm{S}_{\mathrm{t}}=2,611$ & 16 \\
7 & Ondokuz Mayıs & $\mathrm{S}_{\mathrm{t}}=8,928$ & 53 \\
8 & Geyikkoşan (Alaçam) & $\mathrm{S}_{\mathrm{t}}=11,950$ & 71 \\
& Skupaj & $\mathrm{T}_{\mathrm{m}}=84,052$ & $\mathrm{SS}=500$ \\
\hline
\end{tabular}

V anketi smo spraševali po osebni oceni obalnega okolja pred petimi leti in sedaj. Anketa je bila izvedena v turškem jeziku. Anketirali smo prebivalce in uporabnike plaž, stare 18 let in več. Intervju smo izvedli v obliki osebnega intervjuja, ki je trajal okrog pet minut. Do avgusta 2006 smo tako dobili skupno 500 intervjujev, ki smo jih statistično analizirali. Odgovore iz ankete smo za potrebe statistične analize kodirali s programom SPSS. Poleg tega smo plaže na območju raziskave kartirali glede na njihovo uporabo, povzeto po Kocasoyu (1989b) (Slika 2).

Slika 2: Razvrstitev plaž in njihovih meja na območju raziskave (povzeto po Kocasoyu, 1989b). Ključ: 1 - namenjeno samo plavanju in rekreaciji, 2 - namenjeno stanovanjskim objektom, plavanju in rekreaciji, 3 - obstajajo samo stanovanjski objekti, 4 - naravna in umetna pristanišča in zavetišča.

Glej angleški del prispevka.

\section{Rezultati}

$76 \%$ udeležencev ankete je bilo moških, $24 \%$ pa žensk. Razčenitev po starosti anketirancev je podana v sliki 3. Polovica anketirancev se je uvrstila v starostno skupino 24-35 let. Večina (59\%) je imela srednjo izobrazbo, sledijo tisti z univerzitetno izobrazbo (16\%) (slika 4). V anketo smo zajeli tudi veliko število trgovcev $(34 \%)$ in uradnikov (26\%) (slika 5).

Slika 3: Razčlenitev po starosti anketirancev.

Glej angleški del prispevka.

Slika 4: Izobrazba anketirancev.

Glej angleški del prispevka.

Slika 5: Poklici glav družine in uporabnikov plaž.

Glej angleški del prispevka.

Anketiranci so morali odgovoriti na vprašanje »Kateri okoljski problem je po vašem mnenju na tem obalnem območju danes najbolj pereč? « Veljaven odgovor smo dobili pri 500 vzorcih. Devet desetin anketirancev ( $89 \%$ ) je kot prvo izbiro postavilo onesnaženje obalnih morskih voda, kot drugo izbiro so uvrstili onesnaženje plaž (66 \%), izgubo površine plaž in slabo vzdrževanje plaž, kot tretjo izbiro pa spremembo rabe tal, nezadostno odvodnjavanje in prisotnost potepuških psov na plaži (Preglednica 2).

Najpogostejši vir onesnaženja v Samsunu na obali Črnega morja so odpadne vode. Na vprašanje glede vzroka za onesnaženje obalnega območja so skoraj vsi anketiranci $(98 \%)$ kot prvo izbiro postavili »odpadne vode«, $78 \%$ anketirancev je kot drugo izbiro postavilo industrijske odpadke, kot tretjo izbiro pa so na prvo mesto postavili vsakovrstne odpadke z ladij (38\%) (Preglednica 3). 
Preglednica 2: Najpomembnejši okoljski problemi tega obalnega območja z vidika prebivalcev in uporabnikov plaž.

\begin{tabular}{|c|c|c|c|c|c|c|}
\hline \multirow[t]{2}{*}{ problemi } & \multicolumn{2}{|c|}{ 1. izbira } & \multicolumn{2}{|c|}{ 2. izbira } & \multicolumn{2}{|c|}{ 3. izbira } \\
\hline & $\begin{array}{l}\text { pogostnost } \\
(\%)\end{array}$ & $\begin{array}{l}\text { veljavnost } \\
(\%)\end{array}$ & $\begin{array}{c}\text { pogostnost } \\
(\%)\end{array}$ & $\begin{array}{l}\text { veljavnost } \\
(\%)\end{array}$ & $\begin{array}{c}\text { pogostnost } \\
(\%)\end{array}$ & $\begin{array}{c}\text { veljavnost } \\
(\%)\end{array}$ \\
\hline $\begin{array}{l}\text { onesnaženje morske vode na obalnem } \\
\text { območju }\end{array}$ & 89 & 89 & - & - & 1 & 1,5 \\
\hline $\begin{array}{l}\text { onesnženje plaž, izguba površine plaž } \\
\text { in nezadovoljiva infrastruktura na plažah }\end{array}$ & 7 & 7 & 62 & 66,7 & - & - \\
\hline spremembe rabe tal & 4 & 4 & 25 & 26,9 & 60 & 90,9 \\
\hline nezadostno odvodnjavanje & - & - & 6 & 6,4 & 1 & 1,5 \\
\hline potepuški psi & - & - & - & - & 4 & 6,1 \\
\hline ne vem & - & - & 7 & - & 34 & - \\
\hline skupaj & 100 & 100 & 100 & 100 & 100 & 100 \\
\hline
\end{tabular}

$\mathrm{N}=500,16$ na plaži Çınarlık, 260 na Atakum, 30 na Atakent, 34 na İnces, 20 na Taflan, 16 na Dereköy, 53 na Ondokuzmayıs in 71 na plaži Geyikkoşan.

Preglednica 3: Viri onesnaženja obalnih morskih voda.

\begin{tabular}{|c|c|c|c|c|c|c|}
\hline \multirow[t]{2}{*}{ vzrok } & \multicolumn{2}{|c|}{ 1. izbira } & \multicolumn{2}{|c|}{ 2. izbira } & \multicolumn{2}{|c|}{ 3. izbira } \\
\hline & $\begin{array}{c}\text { pogostnost } \\
(\%)\end{array}$ & $\begin{array}{c}\text { veljavnost } \\
(\%)\end{array}$ & $\begin{array}{c}\text { pogostnost } \\
(\%)\end{array}$ & $\begin{array}{c}\text { veljavnost } \\
(\%)\end{array}$ & $\begin{array}{c}\text { pogostnost } \\
(\%)\end{array}$ & $\begin{array}{c}\text { veljavnost } \\
(\%)\end{array}$ \\
\hline odpadne vode & 97 & 98 & 1 & 1,3 & 1 & 2,1 \\
\hline industrijski odpadki & 1 & 1 & 59 & 73,8 & - & - \\
\hline mobilne elektrarne & - & - & 5 & 6.3 & 12 & 25,5 \\
\hline gradivo, ki ga s seboj prinesejo reke & - & - & 9 & 11,3 & 9 & 19,1 \\
\hline odpadna olja z ladij & - & - & 5 & 6,3 & 18 & 38,3 \\
\hline močni nalivi & 1 & 1 & 1 & 1,3 & 7 & 14,9 \\
\hline ne vem & 1 & & 20 & - & 53 & - \\
\hline skupaj & 100 & 100 & 100 & 100 & 100 & 100 \\
\hline
\end{tabular}

Preglednica 3 povzema rezultate, kako javnost zaznava probleme obalnega območja in predstavlja probleme. Anketirance smo vprašali, ali se jim zdi, da so se v zadnjih petih letih problemi obalega območja poslabšali, ostali nespremenjeni, ali pa se izboljšali. Polovica anketirancev $(51,1 \%)$ je navedla, da se površina plaž in količina peska iz različnih razlogov vsako leto manjša (naravno-antropogeni vzroki) in da obstoječe plaže niso zanemarjene (preglednica 4), 37\% anketirancev je odgovorilo, da se je število potepuških psov zmanjšalo, $53 \%$ pa jih meni, da se kakovost potokov, rek in morske vode ni spremenila (preglednica 4).

Preglednica 4: Ali so se v zadnjih petih letih problemi obalnega območja na vašem območju izboljšali, ostali nespremenjeni, ali so se poslabšali?

\begin{tabular}{|c|c|c|c|c|c|c|c|c|}
\hline \multirow[t]{2}{*}{ problemi obalnega območja } & \multicolumn{2}{|c|}{ slabše } & \multicolumn{2}{|c|}{ enako } & \multicolumn{2}{|c|}{ bolje } & \multirow{2}{*}{$\begin{array}{c}\text { brez } \\
\text { odgovora (\%) }\end{array}$} & \multirow{2}{*}{ skupa } \\
\hline & $\begin{array}{c}\text { pogostnost } \\
(\%)\end{array}$ & $\begin{array}{c}\text { veljavnost } \\
(\%)\end{array}$ & $\begin{array}{c}\text { pogostnost } \\
(\%)\end{array}$ & $\begin{array}{l}\text { veljavnost } \\
(\%)\end{array}$ & $\begin{array}{c}\text { pogostnost } \\
(\%)\end{array}$ & $\begin{array}{c}\text { veljavnost } \\
(\%)\end{array}$ & & \\
\hline $\begin{array}{l}\text { kakovost potokov, rek } \\
\text { in morske vode }\end{array}$ & 32 & 33,7 & 50 & 52,6 & 13 & 13,7 & 5 & 100 \\
\hline $\begin{array}{l}\text { odpadki iz industrijskih } \\
\text { in poslovnih con }\end{array}$ & 42 & 45,7 & 38 & 41,3 & 12 & 13,0 & 8 & 100 \\
\hline $\begin{array}{l}\text { zbiranje in predelava } \\
\text { odpadnih materialov }\end{array}$ & 17 & 18,3 & 48 & 51,6 & 28 & 30,1 & 7 & 100 \\
\hline $\begin{array}{l}\text { zmanjševanje površine plaž } \\
\text { in slabo vzdrževanje }\end{array}$ & 46 & 51,1 & 31 & 34,4 & 13 & 14,4 & 10 & 100 \\
\hline potepuški psi & 15 & 16,1 & 43 & 46,2 & 35 & 37,6 & 7 & 100 \\
\hline
\end{tabular}

Naslednje vprašanje je bilo, kateri najpomembnejši problem obalnega območja se je v zadnjih petih letih najbolj poslabšal. $37 \%$ anketirancev je kot najpomembnejši problem postavilo onesnaženje plaž, zmanj- 
šanje površine plaž in pomanjakljivo infrastrukturo na plaži, $22 \%$ uporabnikov plaž pa se je odločilo, da so odpadki tisti najpomembnejši obalni problem, ki se je v zadnjih petih letih najbolj povečal (preglednica 5).

Preglednica 5: Najpomembnejši problemi obalnega območja, ki so se v zadnjih petih letih najbolj poslabšali.

\begin{tabular}{|c|c|c|c|c|c|c|}
\hline \multirow[t]{2}{*}{ problemi obalnega območja } & \multicolumn{2}{|c|}{ 1. izbira } & \multicolumn{2}{|c|}{ 2. izbira } & \multicolumn{2}{|c|}{ 3. izbira } \\
\hline & $\begin{array}{c}\text { pogostnost } \\
(\%)\end{array}$ & $\begin{array}{l}\text { veljavnost } \\
(\%)\end{array}$ & $\begin{array}{c}\text { pogostnost } \\
(\%)\end{array}$ & $\begin{array}{l}\text { veljavnost } \\
(\%)\end{array}$ & $\begin{array}{c}\text { pogostnost } \\
(\%)\end{array}$ & $\begin{array}{c}\text { veljavnost } \\
(\%)\end{array}$ \\
\hline odpadki & 22 & 22 & 26 & 29,5 & 1 & 1,7 \\
\hline onesnaženost obalnih morskih voda & 29 & 29 & 31 & 35,3 & 8 & 13,3 \\
\hline $\begin{array}{c}\text { onesnaženje plaž, zmanjšanje površine } \\
\text { plaž in pomanjkljiva infrastruktura }\end{array}$ & 37 & 37 & 24 & 27,3 & 17 & 28,3 \\
\hline sprememba rabe tal & 12 & 12 & 7 & 7,9 & 34 & 56,7 \\
\hline ne vem & - & - & 12 & - & 40 & - \\
\hline skupaj & 100 & 100 & 100 & 100 & 100 & 100 \\
\hline
\end{tabular}

Ugotovili smo tudi, da se je $39 \%$ anketirancev že udeležilo sestankov, na katerih so obravnavali okoljsko problematiko in dejavnosti, ki naj bi pripomogle $\mathrm{k}$ ohranjanju okolja na obalnem območju (preglednica 6). Pri prvi izbiri se $18 \%$ anketirancev ni odločilo za nobeno od posameznih dejavnosti, pri drugi izbiri jih je bilo $44 \%$ in pri tretji izbiri $68 \%$. Dobljeni rezultati kažejo na to, da se prebivalci in uporabniki plaž ne zavedajo dovolj problemov pri ohranjanju obalnega okolja.

Preglednica 6: Posamezne dejavnosti, ki se izvajajo za ohranjanje obalnega okolja

\begin{tabular}{|c|c|c|c|c|c|c|}
\hline \multirow[t]{2}{*}{ dejavnosti } & \multicolumn{2}{|c|}{ 1. izbira } & \multicolumn{2}{|c|}{ 2. izbira } & \multicolumn{2}{|c|}{ 3. izbira } \\
\hline & $\begin{array}{l}\text { pogostnost } \\
(\%)\end{array}$ & $\begin{array}{c}\text { veljavnost } \\
(\%)\end{array}$ & $\begin{array}{l}\text { pogostnost } \\
(\%)\end{array}$ & $\begin{array}{l}\text { veljavnost } \\
(\%)\end{array}$ & $\underset{(\%)}{\text { pogostnost }}$ & $\begin{array}{l}\text { veljavnost } \\
(\%)\end{array}$ \\
\hline $\begin{array}{l}\text { prisostvovanje na sestankih, ki obravnavajo } \\
\text { okoljske probleme }\end{array}$ & 32 & 39 & - & - & 2 & 6.3 \\
\hline vlaganje zahtev na uradne ustanove & 10 & 12,2 & 17 & 30,4 & - & - \\
\hline $\begin{array}{l}\text { pošiljanje pisem lokalnim } \\
\text { ali nacionalnim časopisom }\end{array}$ & 2 & 2,4 & 5 & 8,9 & 5 & 15,6 \\
\hline $\begin{array}{l}\text { pošiljanje pisem lokalnim uradnikom } \\
\text { ali uradnim ustanovam }\end{array}$ & - & - & 6 & 10,7 & 1 & 3,1 \\
\hline $\begin{array}{l}\text { izdelava tabel, ki opozarjajo } \\
\text { na vzdrževanje čistih plaž }\end{array}$ & 22 & 26,8 & 12 & 21,4 & 10 & 31,3 \\
\hline pobiranje odpadkov na plažah & 6 & 7,3 & 6 & 10,7 & 9 & 28,1 \\
\hline uporaba reciklažnih materialov doma & 10 & 12,2 & 10 & 17,9 & 5 & 15,6 \\
\hline ne vem & 18 & - & 44 & - & 68 & - \\
\hline skupaj & 100 & 100 & 100 & 100 & 100 & 100 \\
\hline
\end{tabular}

Kljub temu pa večina anketirancev pozitivno razmišlja o ohranjanju in nadzorovanju obalnega območja, kar je razvidno iz preglednice 7.

Preglednica 7: Mnenja o ohranjanju in nadzorovanju obalnega območja.

\begin{tabular}{lccccc}
\hline mnenje & da (\%) & $\mathrm{a}(\%)$ & $\mathrm{dd}(\%)$ & $\mathrm{ni}(\%)$ & $\mathrm{t}(\%)$ \\
\hline varstvo okolja mora biti urejeno z zakoni & 62 & 25 & 4 & 9 & 100 \\
vsak naj začne s spremembami pri sebi doma & 24 & 29 & 35 & 12 & 100 \\
obalno okolje je potrebno ohraniti & 44 & 25 & 21 & 10 & 100 \\
$\begin{array}{l}\text { omejiti je treba gradnjo objektov in infrastrure na obalnem } \\
\text { območju, ker predstavlja nevarnost za okolje }\end{array}$ & 44 & 39 & 7 & 10 & 100 \\
$\begin{array}{l}\text { lokalne občine bi morale varovati obalno območje } \\
\text { pred škodljivimi posegi v okolje }\end{array}$ & 52 & 34 & 4 & 10 & 100 \\
\hline
\end{tabular}

Razlaga: DA, Popolnoma se strinjam; A, Se strinjam; DD, Se ne strinjam; NI, Ne vem; T, Skupaj. 
Nazadnje smo anketirance vprašali o njihovih predlogih za preprečevanje onesnaževanja obalnih morskih voda in plaž. Na prvo mesto so postavili čiščenje odplak v čistilnih napravah preden jih izlijejo v morje (71\%), na drugo mesto so postavili gradnjo industrijskih čistilnih naprav (47\%), na tretje mesto pa učinkovito izvajanje predpisov o zaščiti okolja in kaznovanje kršiteljev (preglednica 8).

Nihče ni na prvo mesto uvrstil predloga javnih in nevladnih organizacij, da se organizirajo izobraževalni programi, srečanja, delavnice, tečaji in izdelajo plakati, ki bi pomagali dvigniti raven ozaveščenosti okoljskih problemov. To kaže na dejstvo, da anketiranci menijo, da izobraževanje ne igra dovolj pomembne vloge pri razvijanju ozaveščanja o okoljskih problemih.

Preglednica 8: Predlogi za preprečevanje onesnaževanja obalnih morskih voda in plaž.

\begin{tabular}{|c|c|c|c|c|c|c|}
\hline \multirow[t]{2}{*}{ predlogi } & \multicolumn{2}{|c|}{ 1. mesto } & \multicolumn{2}{|c|}{ 2. mesto } & \multicolumn{2}{|c|}{ 3. mesto } \\
\hline & $\begin{array}{c}\text { pogostnost } \\
(\%)\end{array}$ & $\begin{array}{c}\text { veljavnost } \\
(\%)\end{array}$ & $\begin{array}{l}\text { pogostnost } \\
(\%)\end{array}$ & $\begin{array}{l}\text { veljavnost } \\
(\%)\end{array}$ & $\begin{array}{c}\text { pogostnost } \\
(\%)\end{array}$ & $\begin{array}{c}\text { veljavnost } \\
(\%)\end{array}$ \\
\hline $\begin{array}{l}\text { odplake je treba pred izlitjem } \\
\text { v morje prečistiti }\end{array}$ & 70 & 70,7 & 4 & 4,2 & 1 & 1,3 \\
\hline $\begin{array}{l}\text { zgraditi je treba čistilne naprave } \\
\text { za industriiske odpadke }\end{array}$ & 18 & 18,2 & 45 & 46,9 & 3 & 3,8 \\
\hline $\begin{array}{l}\text { gospodinjske odpadke je potrebno pobirati } \\
\text { po dnevih določenih v razporedu }\end{array}$ & 6 & 6,1 & 16 & 16,7 & 16 & 20,3 \\
\hline $\begin{array}{l}\text { onesnaževalce (fizične in pravne osebe) } \\
\text { je treba prijaviti oblastem }\end{array}$ & 4 & 4 & 20 & 20,8 & 6 & 7,5 \\
\hline $\begin{array}{l}\text { javne in nevladne organizacije naj pripravijo } \\
\text { izobraževalne programe, srečanja, } \\
\text { delavnice, tečaje, posterje, ki bi dvignili } \\
\text { raven zavedanja okoljskih problemov }\end{array}$ & - & - & 8 & 8,3 & 23 & 29,1 \\
\hline $\begin{array}{l}\text { učinkovito je treba kaznovati vse } \\
\text { onesnaževalce okolja }\end{array}$ & 1 & 1 & 3 & 3,1 & 30 & 38 \\
\hline ne vem & 1 & - & 4 & - & 21 & - \\
\hline skupaj & 100 & 100 & 100 & 100 & 100 & 100 \\
\hline
\end{tabular}

\section{Razprava}

V študiji smo podrobno razložili, kako javnost zaznava okoljske probleme obalnega območja in kaj meni o njih kot regionalnem problemu. Na območju raziskave je $89 \%$ prebivalstva in uporabnikov plaž kot prvo izbiro pri problemih obalnega območja navedlo onesnaženje obalnih morskih voda, $7 \%$ anketirancev je navedlo onesnaženje plaž, zmanjševanje površine plaž in pomanjkljivo infrastrukturo na plaži, le $4 \%$ anketirancev pa so navedli spremembo rabe tal (hitra urbanizacija, gradnja stanovanj, prometne ceste; preglednica 2).

Več anketirancev bi lahko onesnaženje plaž, zmanjšanje površine plaž in pomanjkljivo infrastrukturo na plažah postavilo višje mesto. Na tem območju obalna erozija predstavlja očiten problem. Erozija obale in ravnic rečnih delt (Çarşamba and Bafra), ki jo stanovanjska gradnja še pospešuje, že ogroža obalo pri Samsunu (Uzun 2006). Drugi razlog za zmanjševanje površine plaž so naravne razmere oziroima procesi, kot so morski tokovi in obalna erozija. Na plaže vplivajo tudi objekti, ki jih je zgradil človek (jezovi na rekah Yeşilırmak in Kızılırmak, sprehajalne poti in ceste, otroški parki, vrtovi, ilegalno izkopavanje peska). Ilegalno izkopavanje peska se na plaži Geyikkoşan izvaja že več let (Uzun 2005). Şahin (2005a, 109) je ugotovil, da v Turčiji zaradi pospešene gradnje vsako leto izginejo veliki deli plaž. To je vsesplošen problem v Turčiji, pa vendar veliko anketirancev tega ni omenilo kot resen problem. Kot pomemben problem obalnega območja, ki se je v zadnjih petih letih poslabšal, je $37 \%$ anketirancev kot prvo izbiro navedlo onesnaženje plaž, zmanjšanje površine plaž in pomanjkljivo infrastrukturo, $29 \%$ anketirancev je navedlo onesnaženje obalnih morskih voda, $22 \%$ pa odpadke na plažah.

Odpadki predstavljajo najpomembnejši problem obalnega območja, na območju raziskave pa predstavljajo že kritičen oproblem. Zvečer na plažah obleži največ plastičnih delcev, cigaretnih ogorkov ter drugih organskih in neorganskih snovi. Zato občina Atakum na svoji plaži, kjer veliko število obiskovalcev predstavlja velik pritisk na okolje, med poletno sezono vsak večer s posebnim vozilom čisti plažo. Santos in 
ostali (2005) so dokazali obstoj močne povezave med številom obiskovalcev plaž in količino ustvarjenih odpadkov. Pravzaprav so odpadki v morjih in na obalah po vsem svetu postali problem velikih razsežnosti. Projekti, kjer so daljše obdobje beležili količine odpadkov na nemškem delu Severnega morja so pokazali, da plastika obsega 62,5\% vseh odpadkov, ki jih na plaže naplavi morje (Hartwig et al. 2007).

Raba tal, ki je predmet preučevanja geografije, opisuje različne načine, na katere človek izkorišča zemljišča in upravlja z njimi in naravnimi viri. V naseljih Atakum in Atakent, ki v zadnjem desetletju beležita nenehno rast, širijo ceste in gradijo obalne ceste, ki potekajo delno tudi po obali, gradijo parke, otroška igrišča in kavarne, trgajo zemljo morju, vse to pa predstavlja opazen problem obalnega območja. In kljub temu je to kot problem izpostavilo le malo anketirancev (samo $4 \%$ ). İrtem in ostali $(2005,37)$ poudarjajo, da »... se na obalna območja izvaja nenehen in naraščujoč pritisk, ki je posledica problematične rabe tal, na primer hitre urbanizacije, onesnaževanja okolja, razvoja turizma in drugih obalnih dejavnosti...«. Nenehen razvoj obalne urbanizacije in posledično nadomeščanje naravne vegetacije z neprepustnimi površinami bo samo še povečalo odtekanje meteorne vode in onesnaževanje obalnih morskih voda $\mathrm{z}$ različnimi onesnaževali (Malin in ostali 2001).

Skoraj vsi anketiranci menijo, da so odpadne vode najpomembnejši vir onesnaževanja morske vode na obalnih območjih. Rast prebivalstva in turizem so neposredno povezani s problemom odplak. Morsko vodo in plaže pa onesnažujejo tudi drugi dejavniki. Ugotovili so že, da "... so morske naplavine vsi izdelani ali predelani trdni odpadki iz različnih virov, ki se znajdejo v morskem okolju. Štirje glavni viri morskih in obalnih odpadkov so rekreacija in turizem, ribolov, odplake in ladijski odpadki ..." (Santos in ostali 2005, 743). V morjih življenje v morju ogrožajo čezmerno izkoriščanje in ribolov, odlaganje odpadkov, onesnaževanje, tuje vrste, melioracija, poglabljanje dna in globalne spremembe podnebja. Veliko grožnjo življenju v morju predstavlja tudi ena od oblik vpliva človeka, namreč onesnaženje s plastičnimi odpadki (Derraik 2002). Santos in ostali $(2005,745)$ omenjajo izsledke raziskave o ekosistemu, izvedene na obali južne Brazilije, kjer je $54 \%$ aketirancev odgovorilo, da na kakovost plaž najbolj negativno vplivajo odpadki, odplaki ter onesnažena morska voda in pesek. Raziskovali so tudi pravni vidik ilegalnega onesnaževanja obal in morij po svetu z naplavinami, še posebej plastiko, in veliko škodo, ki jo povzroči življenju v morju (Hartwig in ostali 2007, 597). Anketiranci niso omenjali učinkov teh problemov kot enega od vzrokov za onesnaženo obalno morsko vodo. V vsaki anketi pa so bili omenjeni odpadki in naplavine, na primer plastika, kovine, steklo, steklenice od piva in gaziranih pijač, zobne krtačke, šamponi, deodoranti, odplake, vžigalniki, oblačila, obuvala.

Onesnaženost obalne morske vode povzroča resne zdravstvene probleme, še posebej če je vzrok za onesnaženje odpadna voda (Edwin in Geldreich 1975; Langford in ostali 2000). Onesnaženje morja v turističnih območjih, daleč od industrijskih con, se navadno odraža v obliki mikrobiološke onesnaženosti (Kocasoy 1989a), zato lahko onesnažena voda povzroči različne vrste bolezni (glavobol, bruhanje, driska, trebušni tifus, anaerobna griža), ki jih povzročajo patogeni ali mikroorganizmi (Daby in ostali 2002).

Na drugem mestu med dejavniki, ki povzročajo obalne okoljske probleme, je izpust industrijskih odpadkov brez predhodnega čiščenja, kar je navedlo $74 \%$ anketirancev. Rosalind (2000) poudarja, da izpust industrijskih odpadkov brez predhodnega čiščenja negativno vpliva na morske organizme in onesnažuje obalne morske vode. Znanstvene raziskave, ki razlagajo učinek odplak na onesnaženje obalnih morskih voda, podpirajo tudi izsledki omenjenih anket.

Zanimivo je, da nihče od anketirancev ni kot prvo izbiro pri dejavnikih, ki povzročajo onesnaženje obalnih morskih voda, izbral gradiva, ki ga naplavljajo reke. $11 \%$ anketirancev je to gradivo navedlo kot drugo izbiro, $19 \%$ pa kot tretjo izbiro (preglednica 3). Reke Kızılırmak, Yeşilırmak, Kürtün in Mert in potoki so zaradi pogosto močno onesnažene, saj vanje odtekajo tudi izpusti s podeželskih območij. Odpadki po rekah ali s padavinsko vodo pridejo do morja in se odlagajo na na plažah ali v bližini plaž (Williams in ostali 2003).

Odpadne naplavine, ki onesnažujejo plaže in obalno morsko vodo v Samsunu, navadno sestavljajo odpadki, ki jih za seboj pustijo uporabniki plaž, ali pa jih odlagajo reke med hudimi nalivi. Za razliko od rek Kızılırmak and Yeşilırmak, reki Kürtün in Mert izvirata na nadmorski višine od 500 do 1000 metrov in se po 10-15 kilometrih izlijeta $\mathrm{v}$ morje. Zato imata hiter tok in prinašata tudi veliko rečnih naplavin. Ta problem je navedel samo odstotek anketirancev. Drugi vir onesnaženja morskih voda, ki ga omenjajo Santos in ostali (2005) ter Williams in ostali (2003) pa so plavajoči odpadki, ki jih tokovi lahko odnesejo zelo daleč od vira onesnaženja. 
$39 \%$ anketirancev je med dejavnostmi, ki jih posamezniki lahko naredijo za ohranjanje obalnega območja, navedlo udeležbo na srečanjih, kjer so obravnavali okoljsko problematiko, $30 \%$ anketirancev je navedlo vlaganje zahtev na lokalne občine ali uradne ustanove, $31 \%$ anketirancev pa je navedlo opozarjanje na vzdrževanje čistoče na plažah. Tudor in Williams (2006) poudarjata, da uporabniki plaž kot pomembne dejavnike pogosto omenjajo čistočo, možnost rekreacije in naravne značilnosti.

Zanimivo je, da med predlogi za preprečevanje onesnaženja obalnih morskih voda in plaž noben anketiranec ni na prvo mesto postavil predloga javnih in nevladnih organizacij, da se organizirajo izobraževalni programi, srečanja, delavnice, tečaji in izdelajo posterji, da bi se javnost bolj zavedala potrebe po varovanju okolja (preglednica 8). Pa vendar imajo poleg uradnih izobraževalnih ustanov pomembno vlogo tudi prostovoljne organizacije in javnost, ki s pomočjo medijev skrbijo, da bi bila obalna območja bolj čista, primerna in prijetnejša za bivanje. Kombinacija zakonodaje in dvig ekološke ozaveščenosti s pomočjo izobraževanja je verjetno tista pot, ki bi lahko rešila te okoljske probleme (Derraik 2002).

\section{Sklep}

Študija je pokazala, da javnost ni dovolj ozaveščena o problemih obalnega območja. Veliko prebivalcev in uporabnikov plaž pričakuje, da bo te probleme reševala država, vlada, občina ali kdo drug. Vendar je prav javnost najprimernejša za reševanje problemov, obenem pa so prav njej namenjeni okoljski zakoni in pravilniki. Ugotovili smo veliko razliko med resničnimi problemi, kot se odražajo v pokrajini, in med dojemanjem oziroma poznavanjem problemov v obalnem okolju. Postalo je jasno, da se problemi obalnega območja v okrožju Samsun poslabšujejo zaradi človekovega vpliva. Plažam in območjem rečnih delt v Samsunu preti zmanjšanje površine zaradi naravnih dejavnikov (veter, obalni tokovi, granulacija peska) in zaradi vpliva človeka. Obalno območje v Samsunu je čedalje bolj obiskano, okoljska zavest ljudi pa ostaja na nizki ravni. Jasno je, da bodo viri vnosa onesnaževal in njihov učinek na Črno morje naraščali, če se preventivni ukrepi ne bodo izvajali.

To raziskavo je financirala univerzs Ondokuz Mayıs kot projekt št.: F346. Avtor se želi zahvaliti izrednemu profesorju dr. Mehmetu Aliju Cengizu in docentu profesorju dr. Vedatu Sağlamu za pomoč pri tehničnih statističnih metodah in nasvetih.

\section{Literatura}

Glej angleški del prispevka. 